Portland State University

PDXScholar

\title{
Influence of Wetland Landscape Structure on Duck Nest Success at Malheur National Wildlife Refuge, Oregon
}

Daniel Robert Craver

Portland State University

Follow this and additional works at: https://pdxscholar.library.pdx.edu/geog_masterpapers

Part of the Nature and Society Relations Commons, and the Physical and Environmental Geography Commons

Let us know how access to this document benefits you.

\section{Recommended Citation}

Craver, Daniel Robert, "Influence of Wetland Landscape Structure on Duck Nest Success at Malheur National Wildlife Refuge, Oregon" (2010). Geography Masters Research Papers. 9.

https://pdxscholar.library.pdx.edu/geog_masterpapers/9

10.15760/geogmaster.06

This Paper is brought to you for free and open access. It has been accepted for inclusion in Geography Masters Research Papers by an authorized administrator of PDXScholar. Please contact us if we can make this document more accessible: pdxscholar@pdx.edu. 
Influence of Wetland Landscape Structure on Duck Nest Success at Malheur National Wildlife Refuge, Oregon

by

Daniel Robert Craver

A research paper submitted in partial fulfillment

of the requirements for the degree of

Master of Science

in

Geography

Committee:

Jiunn-Der Duh, Chair

Heejun Chang

Keith Hadley

Portland State University

2010 


\begin{abstract}
The decline of waterfowl populations and their requisite wetland habitats remains a concern. Because migratory bird refuges are often artificial landscapes of actively managed wetlands, and wildlife populations experience their greatest change during the breeding season, refuges should be designed to maximize breeding habitat. While past nest success studies have focused on at-nest variables, new approaches are needed to evaluate the effect of composition and configuration of plant communities at the landscape scale. This study aims to quantify landscape patterns within individual refuge management units to determine influence upon historical nesting success averages of ducks at Malheur National Wildlife Refuge in southeastern Oregon. The Mayfield estimate of nest success for 8 duck species yields a survival rate of $25 \%$ for the years $1987-1998$ with a range of $0-74 \%$ across 48 management units. FRAGSTATS was used to calculate a suite of 9 landscape pattern metrics per unit at the class-level for each of 3 wetland habitat classes, and at the landscape-level using all habitat types. These 36 variables were tested for association with survival rate using Pearson $\mathrm{R}$ correlation. Results suggest fragmentation of dry meadow habitat; patch size, complexity, and extensiveness of wet meadow habitat; and diversity of habitats across the landscape positively influence duck nest success at the scale of the individual management unit.
\end{abstract}




\section{ACKNOWLEDGEMENTS}

I thank the U.S. Fish and Wildlife Service for supporting this research, most importantly the past and present staff of Malheur National Wildlife Refuge including Gary Ivey for leading the data collection and time since explaining it to me, Donna Stovall for encouraging graduate research about Malheur, Richard Roy and Jess Wenick for their guidance in the field and toward a biologically relevant project, and the habitat mapping team of Erin Stockenberg and Nick Wilson. I extend my sincere gratitude to the Water Resources Branch, especially Dar Crammond without whose support I would not have been able to complete the program, much less start it, and Tim Mayer for the statistics advice. David Drescher of the Refuge Information Branch additionally provided support for which I am grateful. I am indebted to Brad Bortner and Mike Green of the Division of Migratory Birds who answered my relentless questions about basic bird ecology, as did Dr. Michael Murphy from the Portland State University (PSU) Biology Department who I additionally thank for reviewing the data and directing me toward appropriate methods. I heartily thank all faculty, staff, and associates of the PSU Department of Geography including Carolyn and Robert Perry for their award, Jamie Ludwig for the writing session comradery, and my committee:

Dr. Keith Hadley for inspiration toward the landscape ecological perspective and emphasizing the importance of writing skills, Dr. Heejun Chang for supporting my statistics term paper as a research project, and especially Dr. Geoffrey Duh for his advisement, encouragement, and relentless willingness to help students of geography master the technical skills and ideas to succeed as professionals. 


\section{TABLE OF CONTENTS}

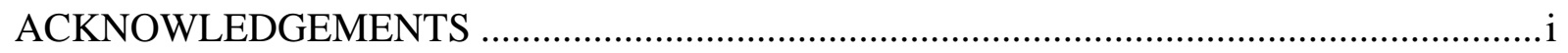

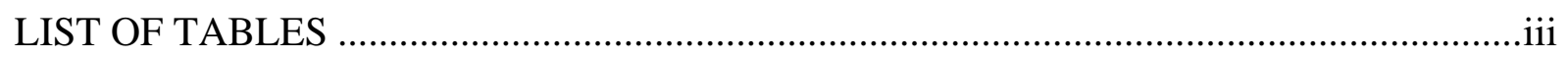

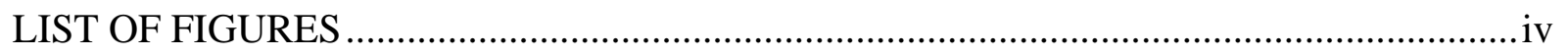

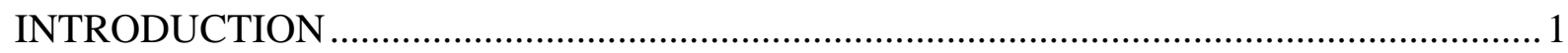

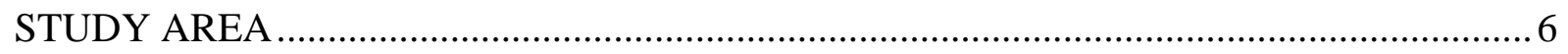

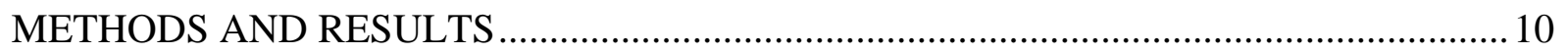

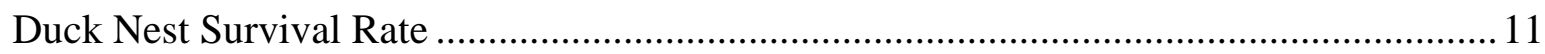

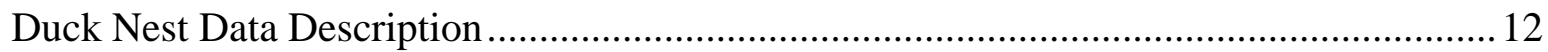

Nest Survival per Field .............................................................................................. 14

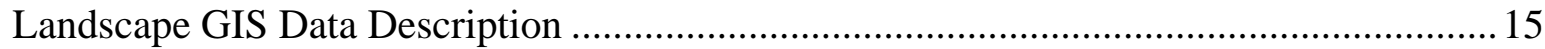

Landscape Metrics Calculation ..................................................................................... 17

Landscape Metrics per Field .................................................................................... 20

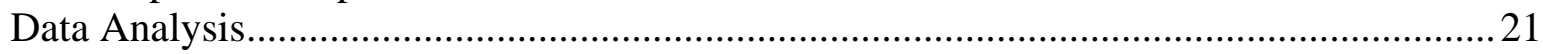

Association between Survival Rate and Landscape Variables ............................................23

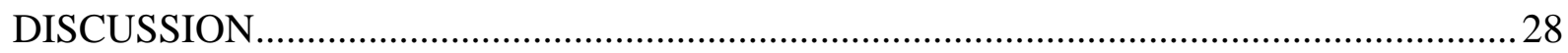

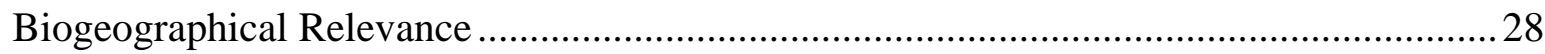

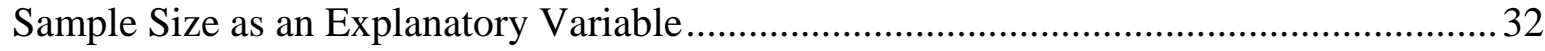

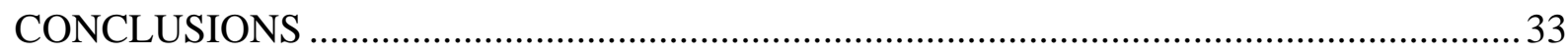

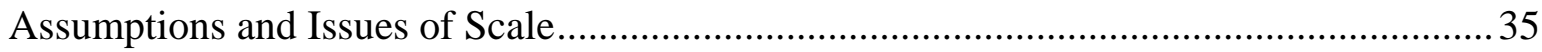

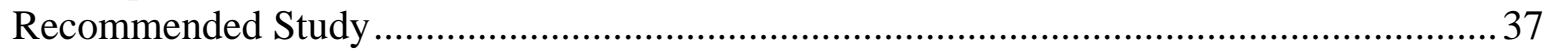

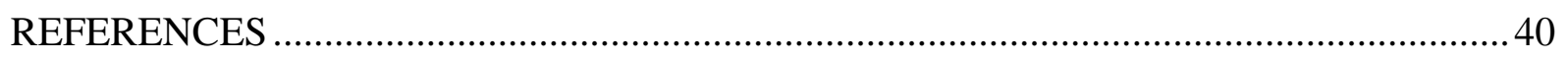

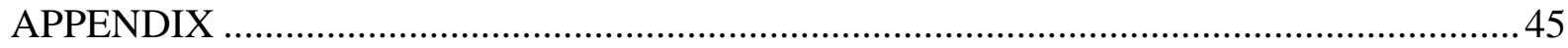




\section{LIST OF TABLES}

Table 1. Review of literature categorized by scale of variables studied.

5

Table 2. Habitat descriptions for the Blitzen Valley and Double O areas of Malheur NWR (USFWS 2010).

Table 3. Duck species represented in the nest data and nesting period data (Bellrose 1980, Klett et al. 1986, and Poole 2009).

Table 4. Survival rate (SR) and sample size (N) of duck nests by field at Malheur NWR 19871998.

Table 5. Landscape metric descriptions (Leitao et al. 2006, McGarigal et al. 2002).............. 18

Table 6. FRAGSTATS Class Properties File................................................................... 19

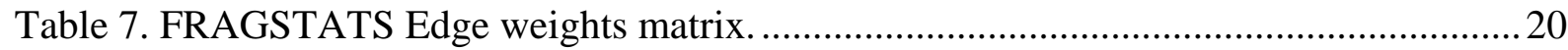

Table 8. Summary statistics of landscape pattern metric for 48 fields. LAND prefixes the landscape-level metrics EM for class-level emergent marsh habitat, WM for wet meadow, and DM for dry meadow (See Table 5 for the descriptions of the metrics)..............................2 21

Table 9. Landscape and class-level metrics correlation (r) and significance (p) values with

Rate. 


\section{LIST OF FIGURES}

Figure 1a. Profile of wetland plant communities along an elevation gradient (USFWS 1990). 2

Figure 1b. Spatial arrangement of wetland plant communities by water regime (Olson 1999). 2

Figure 2. Location of Malheur National Wildlife Refuge in Southeast Oregon and major water

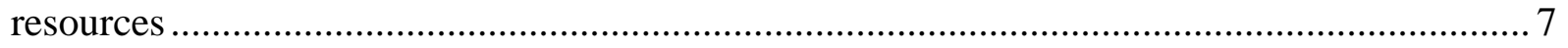

Figure 3. Management fields and land-cover habitat types of Blitzen Valley and Double O

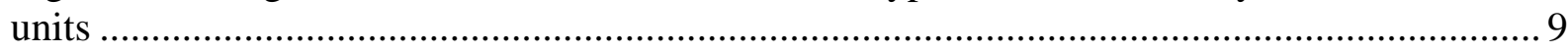

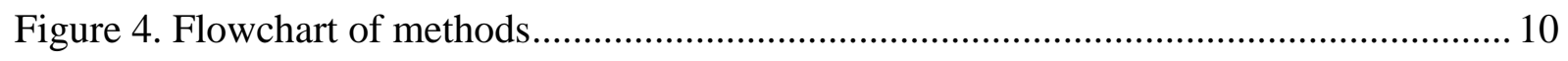

Figure 5. Boxplots of Survival Rate and log transformation of Rate .................................. 24

Figure 6. Scatterplot and regression line for Rate $~$ landscape-level metric Patch Richness

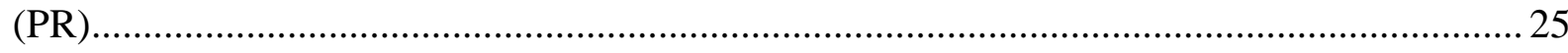

Figure 7. Scatterplots and regression lines for Rate $\sim$ wet meadow class-level metrics Mean Patch Size (AREA), Radius of Gyration (GYRATE), and Shape (SHAPE) ........................ 26

Figure 8. Scatterplot and regression line for Rate $\sim$ dry meadow class-level metric Patch

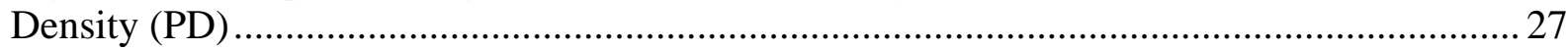

Figure 9. Fields with four highest and lowest survival rates (SR) and signififcant landscape

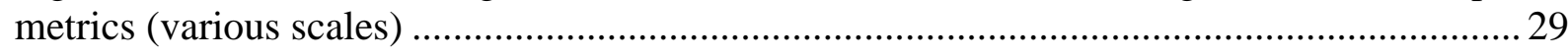

Figure 10. Scatterplot and regression line for Rate $~$ Sample Size .................................... 33 


\section{INTRODUCTION}

The primary reason for decline of duck populations is loss of wetland habitats (Bellrose 1980). Wetland area in North America continues to decrease by approximately 60,000 acres each year (EPA 2009). Wildlife refuges established for migratory birds attempt to mitigate these losses by constructing and managing wetland landscapes representing a variety of habitat types. Because wildlife experience the greatest change in population during the breeding season, nest success is the key variable in the population dynamics of many birds (Aebischer 1999, Rotella 2008). Refuge landscapes, therefore, should be designed to support nesting habitat requirements.

The National Wildlife Refuge System (NWRS) conserves species populations by preserving and managing habitat (USFWS 1976). Wetland restoration and creation has become an increasingly important part of remediating the continuing decline of wetlands nation-wide (USFWS 2003). Refuges are often established on lands that were historically wetlands and floodplains prior to flood control and channelization and in areas suitable for the creation of artificial wetlands (USFWS 2003). The most significant practices on refuges includes the manipulation of land and water (USFWS 1976). Habitat is recreated and maintained by construction and active management of water system infrastructure, such as dikes, canals, impoundments, and dams (USFWS 2003). As of 2003, the NWRS actively manages 1.6 million acres of wetlands on refuges (USFWS 2003).

Topography and irrigation practices influence the spatial arrangement of wetland plant communities that comprise various types of habitat. Wetland impoundments, or ponds, are 
usually depressions surrounded by a rising elevation gradient that dictates the water regime and resulting vegetative response (Figures 1a and b). The core area of a managed wetland is usually open water that provides birds with foraging for aquatic vegetation and invertebrates (Fredrickson and Taylor 1982), and escape from mammalian predators. Surrounding the open water is a ring of semi-permanently flooded tall emergent marsh vegetation that provides cover (Baldassare and Bolen 1994). Seasonally flooded wet meadow, temporarily flooded dry meadow, and non-irrigated upland habitat sequentially occur at higher elevations, each with decreasing height of vegetation (Cowardin et al. 1979). In contrast to deliberate impoundment of water for pond management, seasonal flood irrigation of relatively flat fields results in large areas of dry or wet meadows with pockets of emergent marsh vegetation in shallow depressions. Drier meadows are typically characterized by grass and sedge communities dictated by the depth and duration of water application (Baldassare and Bolen 1994).

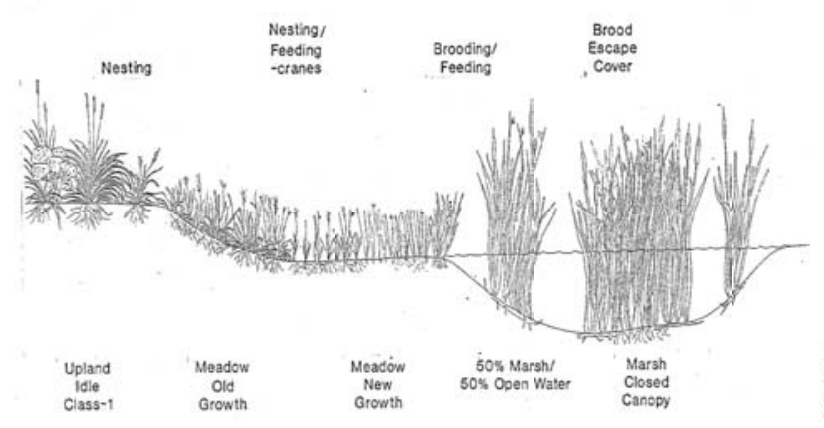

Figure 1a. Profile of wetland plant communities along an elevation gradient (USFWS 1990).

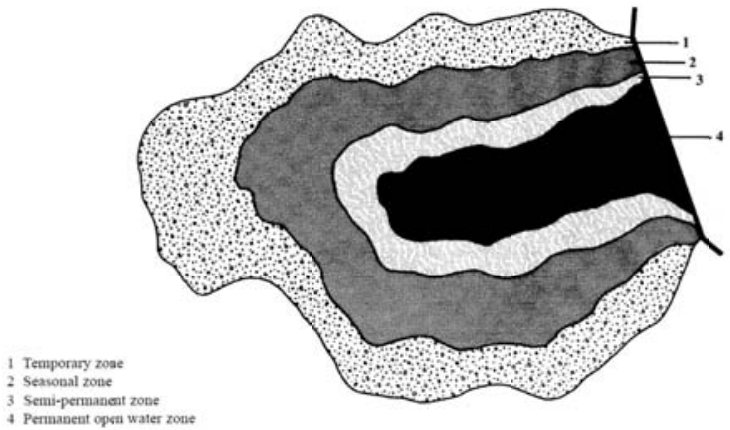

Figure 1b. Spatial arrangement of wetland plant communities by water regime (Olson 1999).

The spatial arrangement of patches of plant communities within a specified area can be quantified using landscape pattern metrics (Leitao et al. 2006). Landscapes are defined as a mosaic of patches that are the basis of categorical maps (McGarigal et al. 2002). Patches are 
defined as relatively homogenous non-linear areas that are different from their surroundings (Forman 1995). Calculation of landscape pattern metrics relies on the patch-matrix model of landscapes, where the matrix is conceptually the most extensive and connected landscape element (Forman 1995). In practice, the matrix is comprised of patch types considered background to the patch type or types under investigation (McGarigal et al. 2002).

Landscape structure is characterized by its composition and configuration of landcover. Composition includes the categorical type of landscape components, or patches, whereas configuration provides spatial context in absolute and relative space by measures of location and placement of patches in a mosaic. Measures of composition and configuration can be computed at three levels: patch, class, and landscape. Patch-level metrics are descriptive statistics about individual patches and involve measurements of size, perimeter, and shape about individual areas. Class-level metrics consider all patches of a single type, or class, across a landscape and provide a measure of fragmentation. Landscape-level metrics use all classes, or patch types, in their calculation and represent a measure of heterogeneity for the entire landscape mosaic. Higher level class and landscape-level metrics are computationally dependent on lower level patch metrics (McGarigal et al. 2002). While patch-level indices alone do not characterize the landscape, they have been a dominant theme in avian habitat ecology stimulated by island biogeographic theory (MacArthur and Wilson 1967), and compliment non-spatial explanatory data traditionally collected for nest success research.

Past studies (Table 1) have found patch-level metrics can predict reproductive success of ground-nesting birds (Bellrose 1980, Horn et al. 2005, Paton 1994, Skagen et al. 2005, 
Stephens et al. 2003). Bellrose (1980) for example, found waterfowl restricted to a narrow band of nest cover surrounding a wetland have greater exposure to predators. Horn et al. (2005) discovered a statistically significant relationship with patch size and duck nest success in the prairie grasslands of North Dakota. Skagen et al. (2005) found nest survival of ground nesting birds increased with patch size up to 65 ha in northeastern Colorado, citing a lack of difference in larger patches to difference in predator communities in their study. Metaanalyses of literature has further established evidence of a positive relationships between patch size and nest success (Paton 1994), and a detectable effect of fragmentation at the patch-scale (Stephens et al. 2003).

Use of class and landscape-level metrics to quantify landscape beyond the patch boundary is sparse among studies of nest success (Stephens et al. 2003). Passinelli and Schiegg (2006) studied nest success of a ground nesting bird species in Switzerland at four spatial scales to find nest predation increased with distance to nearest wetland. Species occurrence, abundance, and richness are measures of wetland bird productivity more often studied for relation to landscape scale variables. The amount of wetland habitat available across a landscape has been found to directly influence these measures (Fairbairn and Dinsmore 2001, Naugle et al 1999, Riffell et al. 2003, and Taft and Haig 2006). Riffell et al. (2003) suggest future landscape-level research should include demographic data such as nest success to compliment studies of wetland bird productivity. 


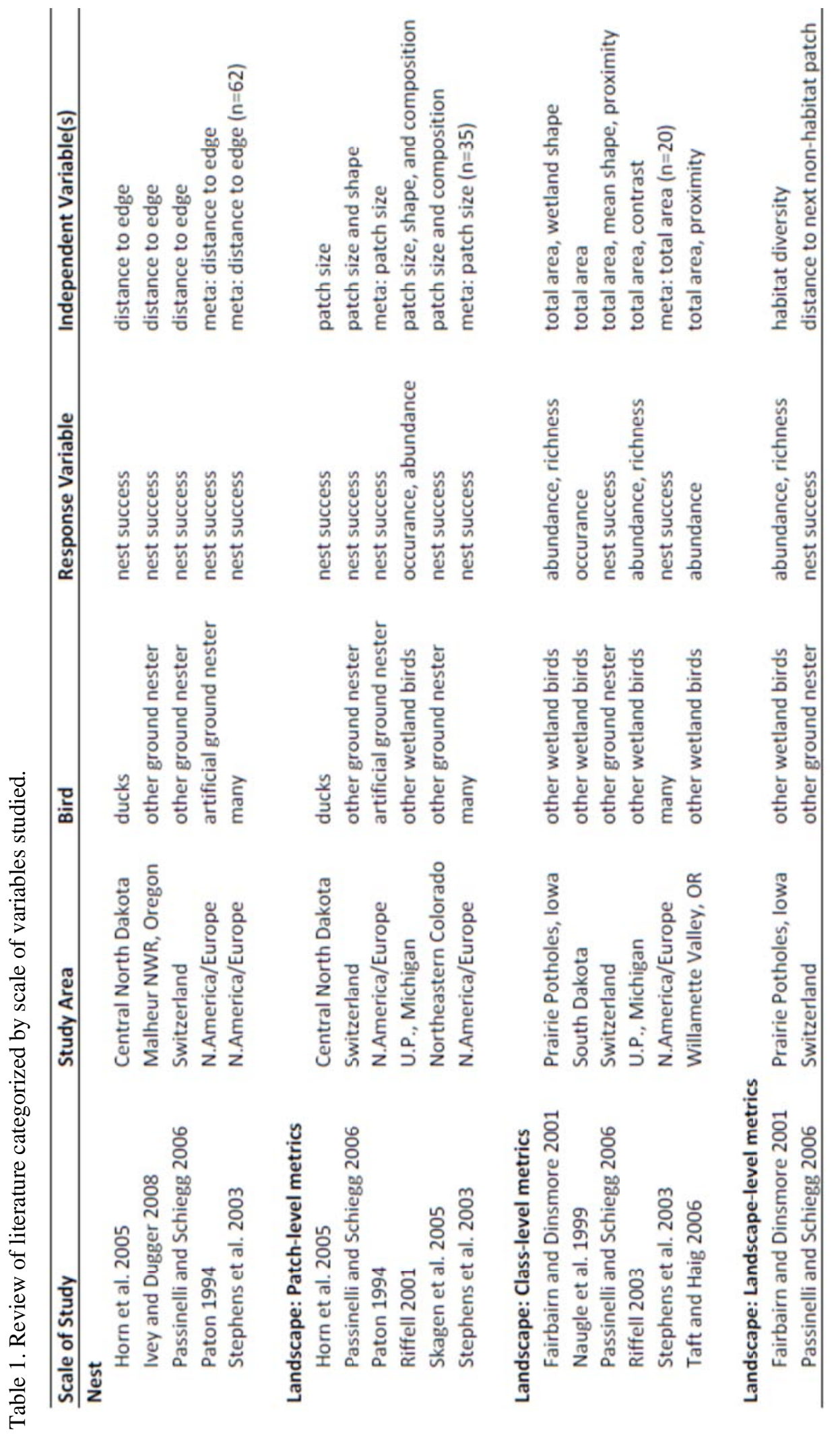


The goal of my research is to explore the relationships between landscape structure beyond the individual patch and nest success of ducks in the actively-managed wetlands at Malheur National Wildlife Refuge (NWR) in southeastern Oregon. My hypothesis is that class and landscape-level composition and configuration of wetland habitat types influence duck nest success. Similar to most refuge landscapes, the Malheur NWR is a mosaic of landcover habitat types managed at the landscape scale. As a result, determining landscape influences on nest success may offer insights toward the optimal design and management of migratory bird habitat.

\section{STUDY AREA}

Malheur National Wildlife Refuge (Refuge) is an 187,000 acre complex of freshwater riparian wetlands surrounded by high-desert uplands (4100' above MSL) in the Interior Columbia Basin ecosystem (Figure 2). The Refuge was established by the U.S. Fish and Wildlife Service (USFWS) in 1908 to conserve Malheur, Mud, and Harney Lakes for migratory birds (Cornely 1982, Langston 2003). Malheur Lake is the largest freshwater marsh in the Western United States and historically highly productive for water birds (Cornely 1982). In 1935, the Donner und Blitzen River Valley, and in 1942 the Double O Ranch, were added to the Refuge to protect water sources to the lakes and additional breeding habitat. The Refuge provides habitat to over 320 bird species at various times of the year and is an important breeding ground to migratory birds along the Pacific Flyway (Cornely 1982, Langston 2003). 


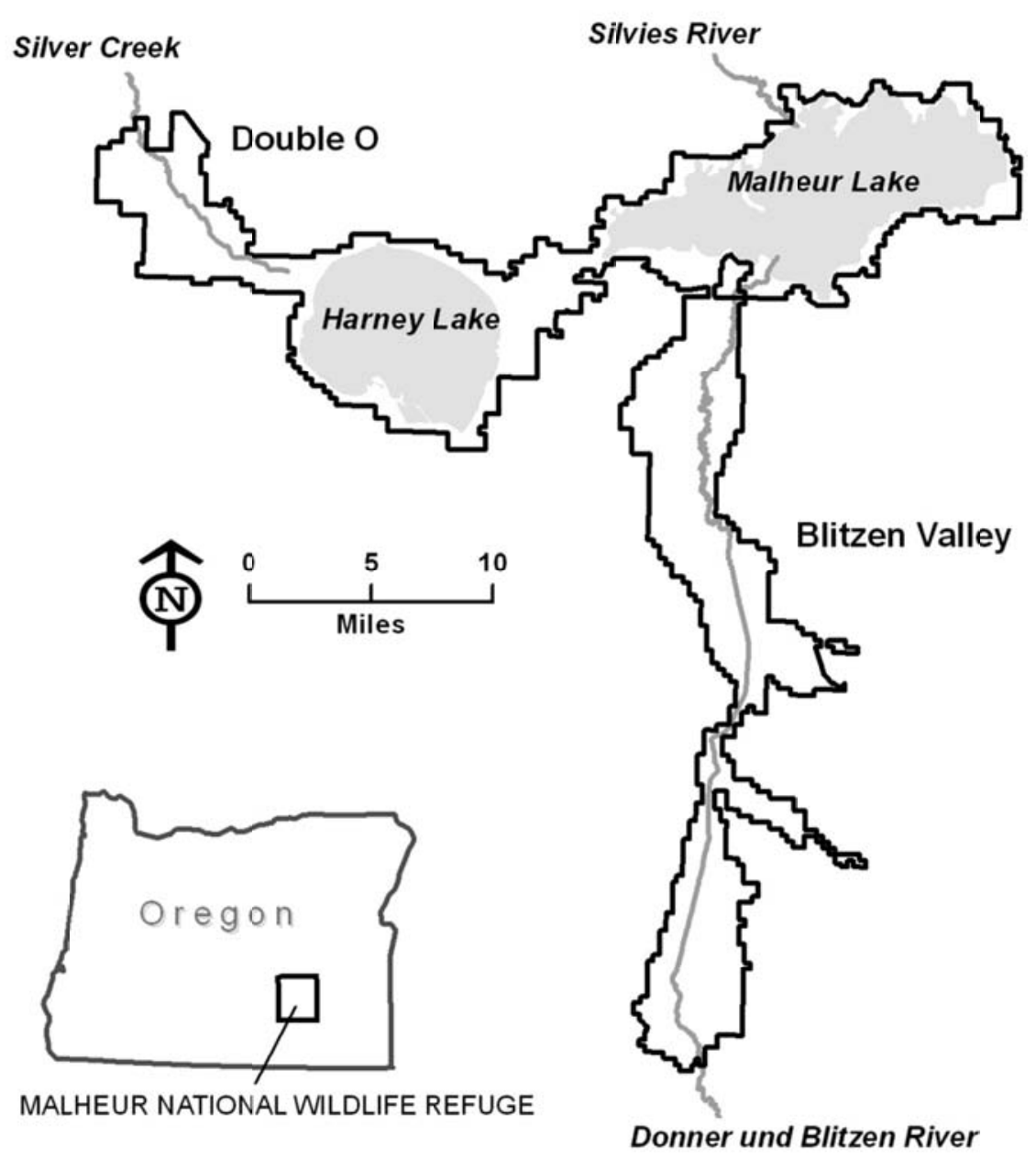

Figure 2. Location of Malheur National Wildlife Refuge in Southeast Oregon and major water resources.

Avian productivity of Malheur Lake declined in the late 1940s, assumed to be a result of common carp (Cyprinus carpio) infestation (Ivey et al. 1998). This placed a greater management emphasis on the Blitzen Valley and Double $\mathrm{O}$ areas to support Flyway needs. These areas are comprised of 120 named fields (101 and 19 respectively), averaging 100 hectares in size, segregated by roads, dikes, and fences (Figure 3). These fields serve as the basic unit of management to meet habitat objectives. Each field possesses a unique composition and configuration of land-cover habitat types (Table 2). The landscape structure 
within these fields is controlled with irrigation infrastructure constructed before and during the early establishment of the Refuge (Langston 2003). This system includes more than 1000 water control structures and an extensive network of canals to distribute spring runoff from the Donner und Blitzen River and Silver Creek (Figure 2). Habitat objectives are met by adjusting the timing and amount of water applied to each field to grow a specific type and abundance of vegetation. These habitat objectives are developed to meet the Refuge's wildlife population goals. A better understanding of the relationship between habitat landscape structure and nest success may help Refuge managers meet their avian population goals.

Table 2. Habitat descriptions for the Blitzen Valley and Double O areas of Malheur NWR (USFWS 2010).

\begin{tabular}{|c|c|c|}
\hline Land-cover Habitat Type & Ecosystem & Description \\
\hline Dry Meadow (DM) & wetland & $\begin{array}{l}\text { 50-70\% cover live native grasses e.g., creeping wildrye (Leymus } \\
\text { triticoides) }\end{array}$ \\
\hline Emergent Marsh (EM) & wetland & Dominated by emergents e.g, harstem bullrush (Scirpus acutus) \\
\hline Open Water & wetland & $\begin{array}{l}\text { Includes submergent vegetation e.g., sago pondweed } \\
\text { (Potamogeton pectinatus) }\end{array}$ \\
\hline Wet Meadow (WM) & wetland & $\begin{array}{l}75 \% \text { cover water-tolerant grasses, rushes (Juncus spp.), and } \\
\text { sedges (Carex spp.) }\end{array}$ \\
\hline Playa & upland & Predominantly bare ground, hypersaline shallow flooding \\
\hline Public Use Area & upland & $\begin{array}{l}\text { Developed areas for public use incl. parking, wildlife } \\
\text { observation, amenities }\end{array}$ \\
\hline Riparian Shrub & wetland & 40-80\% canopy cover native shrubs e.g., willow (Salix spp.) \\
\hline Riverine & wetland & Linear water conveyance features such as rivers and canals \\
\hline Sagebrush Lowlands & upland & $\begin{array}{l}20 \% \text { cover sagebrush species (Artemisia tridentata ssp.), } \\
\text { elevated areas in valley }\end{array}$ \\
\hline Sagebrush Steppe & upland & $\begin{array}{l}20 \% \text { cover sagebrush species (Artemisia tridentata ssp.), above } \\
\text { surrounding rim }\end{array}$ \\
\hline Salt Desert Scrub & upland & $\begin{array}{l}<15 \% \text { cover shrubs e.g., greasewood (Sarcobatus spp.), }<20 \% \\
\text { herbaceaous veg }\end{array}$ \\
\hline
\end{tabular}




\section{Double 0}

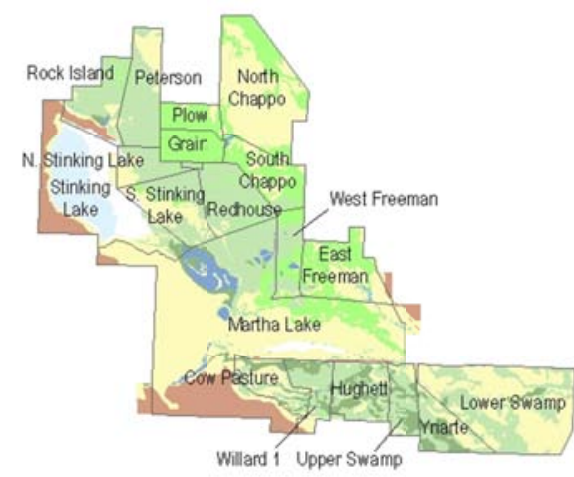

\section{Habitat Types}

Dry Meadow

Emergent Marsh

Open Water

Wet Meadow

Playa

Public Use Area

Riparian Shrub

Riverine

Sagebrush Lowlands

Sagebrush Steppe

Salt Desert Scrub
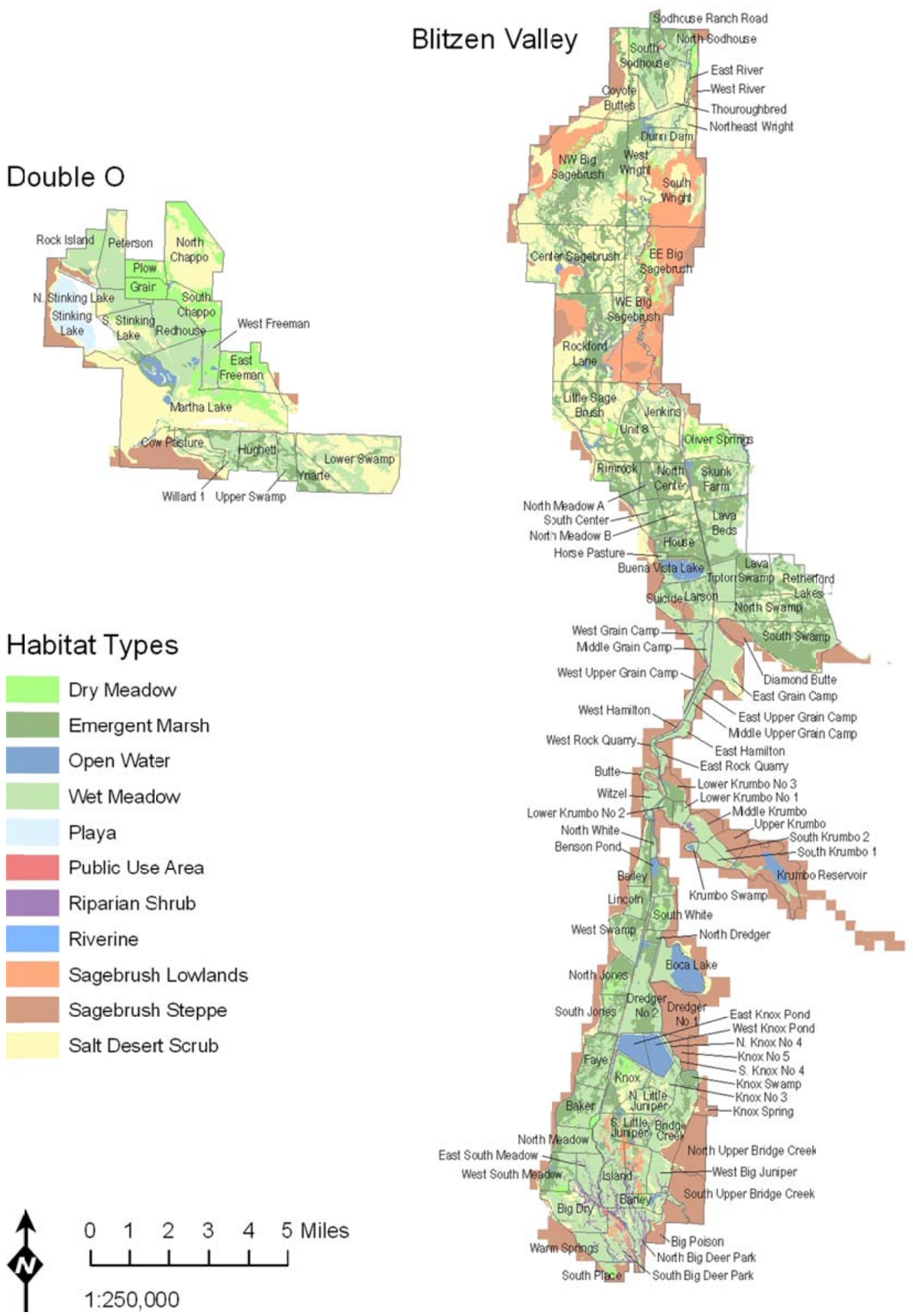

Figure 3. Management fields and land-cover habitat types of Blitzen Valley and Double O units. 


\section{METHODS AND RESULTS}

My methods focused on developing estimates needed to assess the relationship between bird nest success and landscape structure using secondary data. First I estimated Mayfield survival rates of nest success to create a long-term average for fields within the Blitzen Valley and Double-O areas of the Refuge. Second, I calculated class and landscapelevel metrics for fields having a suitable survival rate sample size from a land-cover habitat map using FRAGSTATS software. I then examined the relationship between duck nest survival rate and landscape pattern metrics using descriptive statistics and correlation analysis (Figure 4).

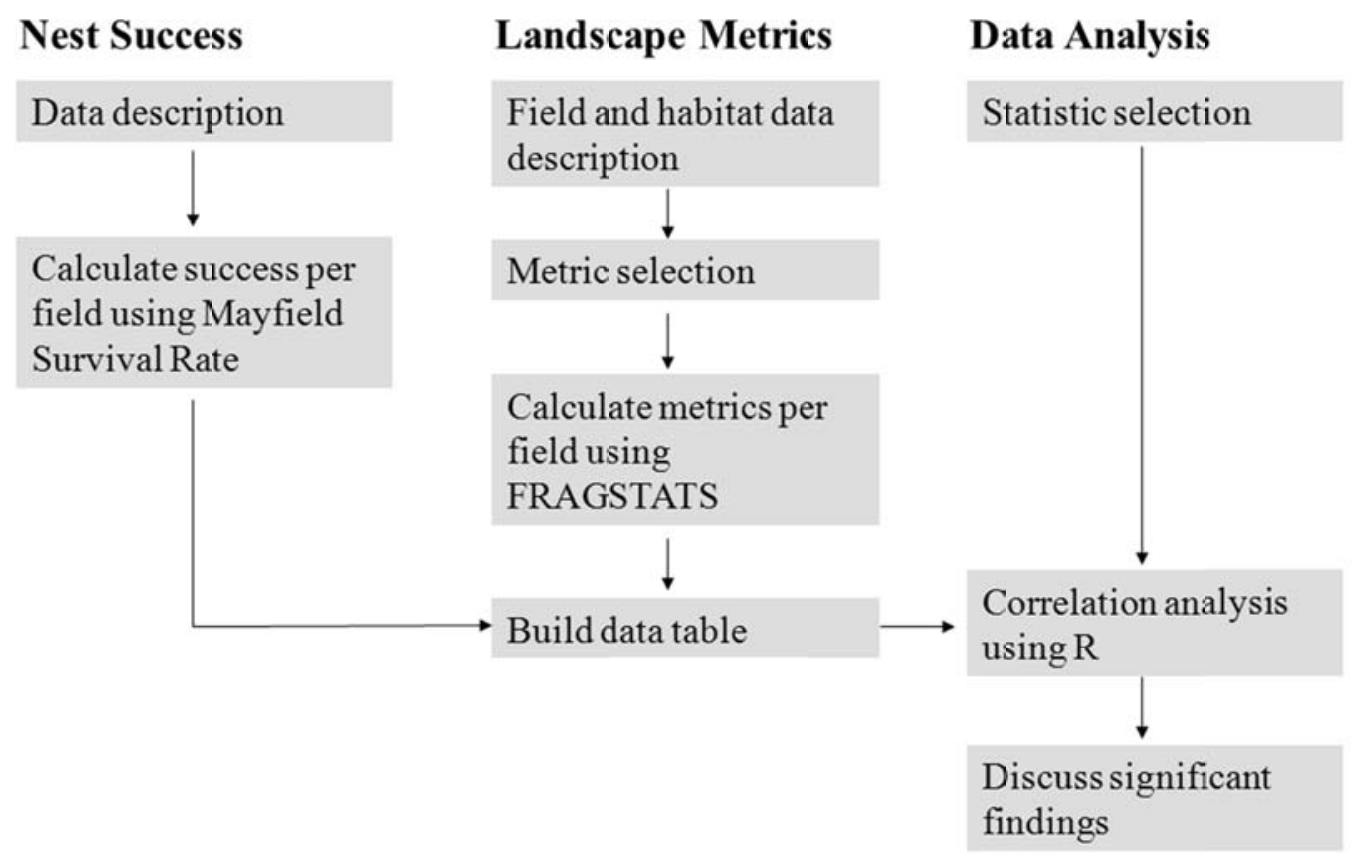

Figure 4. Flowchart of methods. 


\section{Duck Nest Survival Rate}

The Mayfield survival rate method is appropriate to create an estimate from pooled nest success data (Mayfield 1961, 1975). This method alleviates limitations with the apparent nest success method. Apparent nest success is calculated by dividing the number of successful nests by the total number of nests found. Because successful nests are more likely to be found than failed nests, this procedure often over estimates nest success. Nest survival considers the unit of analysis to be the number of days a nest is under observation, and subsequently exposed to failure, rather than the individual nest. Daily Survival Rate (DSR) is first calculated to estimate the probability of a nest surviving from one day until the next. Survival Rate (SR) is then calculated by raising DSR to the power of the number of days in the nesting period. The nesting period is equal to the sum of the laying and incubation periods.

$$
\begin{gathered}
\text { DSR }=1-\left(\frac{\text { no. failed nests }}{\text { no. exposure days }}\right) \\
S R=D S R \wedge \text { length of nesting period in days }
\end{gathered}
$$

Nest success is therefore estimated using the method described by Mayfield (1961, 1975), modified by Johnson (1979) and described in detail by Klett et al. (1986). For long intervals between visits, as is common in waterfowl studies, the midpoint assumption provides too much exposure to failed nests (Johnson 1979). To minimize disturbing nesting hens, waterfowl researchers often do not revisit until after the calculated hatch date (Johnson 1979). Therefore, $40 \%$ of the number of days between visits is used to estimate exposure 
when searches were more than 14 days apart (Johnson 1979), otherwise half the interval between visits is used. Estimate of exposure days for successful nests, average clutch size and incubation period for eight duck species (Table 3) were derived from Bellrose (1980), Klett et al. (1986), and Poole (2009). Data were censored if missing a first and last visitation date, or if fate was unknown and lacking an egg count (Ivey 2009).

Table 3. Duck species represented in the nest data and nesting period data (Bellrose 1980, Klett et al. 1986, and Poole 2009).

\begin{tabular}{|c|c|c|c|c|c|c|c|}
\hline SPECIES & & TYPE & (n) & $\begin{array}{c}\text { CLUTCH } \\
\text { (avg) }\end{array}$ & $\begin{array}{c}\text { CLUTCH } \\
\text { (max) }\end{array}$ & $\begin{array}{c}\text { INCUBATION } \\
\text { (days) }\end{array}$ & $\begin{array}{c}\text { EXPOSURE } \\
\text { (days) }\end{array}$ \\
\hline Canvasback (CANV) & Aythya valisineria & diving & 71 & 10 & 12 & 26 & 36 \\
\hline Cinnamon Teal (CITE) & Anas cyanoptera & dabbling & 231 & 9 & 16 & 24 & 33 \\
\hline Gadwall (GADW) & Anas strepera & dabbling & 252 & 10 & 12 & 25 & 35 \\
\hline Green-winged teal (AGWT) & Anas crecca & dabbling & 3 & 9 & 9 & 24 & 33 \\
\hline Mallard (MALL) & Anas platyrhynchos & dabbling & 474 & 9 & 13 & 26 & 35 \\
\hline Northern Pintail (NOPI) & Anas acuta & dabbling & 69 & 8 & 12 & 24 & 32 \\
\hline Northern Shoveler (NSHO) & Anas clypeata & dabbling & 51 & 10 & 12 & 24 & 34 \\
\hline Redhead (REDH) & Aythya americana & diving & 124 & 10 & 14 & 25 & 35 \\
\hline
\end{tabular}

A nest was defined as having at least one egg and was considered successful if at least one egg hatched (Klett et al. 1986). I assumed parasitism occurred if the number of eggswhen-found was two more than the maximum number of eggs as reported by Poole (2009). In this case I used the average clutch size as reported by Klett et al. (1986) to calculate number of exposure days.

\section{Duck Nest Data Description}

Duck nest success data collected by Refuge staff and volunteers during the years 1987-1998 was received in Microsoft Excel spreadsheet format (USFWS 2010). Nests were opportunistically surveyed in multiple fields across the Blitzen Valley and Double-O areas (Figure 3). Most nests were visited twice to determine activity and fate (Ivey and Dugger 
2008). Eight species of ducks are represented in the data totaling 1275 records (Table 3) with 598 hatched, 563 failed, and 114 of unknown fate. The dataset includes the data required to calculate nest survival; date found, number of eggs when found, age of nest when found, date of last visit, and fate; and potential explanatory variables including the plant community surrounding the nest; emergent marsh (EM), wet meadow (WM), or dry meadow (DM). I consider these three land-cover classes to comprise the entirety of wetland habitat for nesting requirements.

Location data includes the field name within which the nest was found, however, lack spatial coordinates of the individual nests since commercial handheld Global Positioning System (GPS) technology was not available during the census period. This precludes landscape-ecological analysis at the patch level and depends on averaging the nest success within each field for analysis with class and landscape-level metrics.

Though species of dabbling ducks have somewhat different nesting chronology and habitat preference, Horn et al. (2005) found nests of all species intermingled in space and time and therefore appropriate to pool nest data across all species within each field. I assume survival is equally probable for all species. Predation is the primary reason for nest failure $(376 / 563=67 \%)$ as opposed to abandonment $(176 / 563=31 \%)$. Predators do not discriminate among duck species and abandonment occurs for reasons such as weather, flooding, and disturbance, to which all species are equally subjected. Further, I assumed the landscape within each field had not changed between years because wetland plant communities serving as duck nesting habitat are largely perennial (Guard 1995), and there have been no geomorphic events, nor large-scale management actions (USFWS 2010) to influence the 
distribution of habitat within the time period examined. I assumed the range of influence of inter-annual variables, such as weather, surrogate prey populations, and predator control practices, are represented within the 11 year period of these data and therefore do not bias the long-term average. Pooling data across species and years provides a more robust estimate of historic survival rate for each field.

\section{Nest Survival per Field}

I calculated the Mayfield Nest Survival Rate to assign an average nest success for each field (Table 4). The Malheur Lake and Martha Lake fields were removed because their boundaries encompass a disproportionate amount of unmanaged land containing habitat classes not found in the other fields. Hensler and Nichols (1981) used simulation testing to determine a minimum sample size of 20 nests is needed to estimate survival with any precision. Using less than 20 nest records to calculate survival rate may misrepresent the influence of landscape metrics in any one field, however, I chose an arbitrary minimum of 5 to retain some sample of nests for estimating average success while producing a suitable sample size of fields for correlation analysis. The total sample size after censoring is 956 nests. I pooled nest data across species and years to achieve an average $19.9 \pm 17.0$ nests per field for survival calculation across 48 fields. The range is 5 to 77 nests with 30 fields having less than 20 nests. The mean survival rate is $25 \% \pm 17 \%$ with a range of 0 to $74 \%$. 
Table 4. Survival rate (SR) and sample size (N) of duck nests by field at Malheur NWR 1987-1998.

\begin{tabular}{lcclcc}
\hline FIELD & N & SR & FIELD & N & SR \\
\hline Bailey & 5 & 0.13 & North Swamp & 14 & 0.25 \\
Baker & 68 & 0.31 & NW Big Sagebrush & 12 & 0.17 \\
Boca Lake & 30 & 0.26 & Peterson & 12 & 0.22 \\
Bridge Creek & 20 & 0.42 & Redhouse & 24 & 0.44 \\
Center Sagebrush & 10 & 0.25 & Rock Island & 6 & 0.62 \\
Dredger No 2 & 46 & 0.17 & Rockford Lane & 8 & 0.38 \\
East South Meadow & 5 & 0.03 & Skunk Farm & 9 & 0.59 \\
EE Big Sagebrush & 8 & 0.39 & South Center & 6 & 0.09 \\
Faye & 32 & 0.21 & South Chappo & 5 & 0.06 \\
Grain & 7 & 0.00 & South Jones & 52 & 0.29 \\
House & 28 & 0.18 & South Krumbo & 5 & 0.02 \\
Hughett & 6 & 0.04 & South Little Juniper & 25 & 0.42 \\
Island & 46 & 0.21 & South Swamp & 25 & 0.04 \\
Knox & 77 & 0.26 & South White & 25 & 0.27 \\
Larson & 41 & 0.15 & Suicide & 9 & 0.06 \\
Lava Beds & 10 & 0.74 & Thoroughbred & 9 & 0.03 \\
Little Sage Brush & 6 & 0.15 & Tipton & 18 & 0.28 \\
Middle Krumbo & 14 & 0.41 & West Big Juniper & 9 & 0.07 \\
North Dredger & 48 & 0.42 & West Grain Camp & 7 & 0.31 \\
North Jones & 38 & 0.34 & West South Meadow & 15 & 0.33 \\
North Little Juniper & 11 & 0.30 & West Swamp & 9 & 0.15 \\
North Meadow & 28 & 0.42 & West Wright & 14 & 0.43 \\
North Meadow A & 10 & 0.21 & Willard 1 & 12 & 0.05 \\
North Sodhouse & 21 & 0.36 & Yriarte & 11 & 0.11 \\
\hline
\end{tabular}

\section{Landscape GIS Data Description}

Landscape metrics were calculated for habitat types within individual fields using data received from the Refuge (USFWS 2010). The Comprehensive Conservation Planning (CCP) process currently in progress at the Refuge requires map data compiled in a Geographic Information System (GIS). These data include field boundaries and land-cover to describe habitat received as ESRI geodatabase vector format feature classes. The field boundaries were digitized from scanned and georeferenced historic maps and reviewed by Refuge staff for correct names and locations. The dataset was further spatially validated with GIS data of fence-lines, roads, dikes, and canals mapped using GPS and air photo interpretation (NAIP 
2005). Fifteen land-cover categories, including the three wetland nesting habitat classes, describe all habitat types pertinent to Refuge management and the CCP effort. Dunes, lava flows, and springs habitat classes occur at a spatial scale or distribution irrelevant to this study, and the category lake basin occurs outside the management areas, resulting in 11 mapped land-cover categories (Table 2). The dataset was initially created by merging: 1) soils GIS data developed in 1997 by the Natural Resources Conservation Service (NRCS 2006) and 2) wetlands developed using aerial photography from 1974 and 1983, and validated with field visits in 1984, by the National Wetlands Inventory (NWI 1986). The data was updated with field-reference data collected using GPS in 2010, and air photo interpretation (NAIP 2005). Accuracy assessment using the field-reference data results in an overall accuracy of $81 \%$. Though vegetative land-cover conditions change within and between years, the purpose of this dataset is to describe objective habitat, not habitat availability, and carries the assumption that plant community composition and configuration did not change during the time period of the contributing datasets (USFWS 2010).

Preparing the GIS data for use with FRAGSTATS consisted of clipping habitat data to the field boundaries and converting to raster format. In landscape-ecological terms, the extent of the scale is therefore defined by the field boundary and varies in size for each field. McGarigal et al. (2002) recommend a cell size that is less than half the narrowest dimension of the smallest patches to retain necessary spatial resolution of the vector data and subsequently represent the configuration of the land-cover classes. The clipped habitat data were converted to raster datasets in ASCII format with $10 \mathrm{~m}$ resolution. The $10 \mathrm{~m}$ cell size thus represents the grain of the scale in landscape-ecological terms. 


\section{Landscape Metrics Calculation}

Though landscape metrics do not always provide definitive quantitative information, they often provide comparative information useful for ranking options and lending insight toward future study (Leitao et al. 2006). A suite of landscape metrics described by Leitao et al. (2006) were calculated using FRAGSTATS software (McGarigal et al. 2002) and the raster habitat map of the Refuge. FRAGSTATS offers hundreds of landscape metrics that can be calculated, however, most of them are redundant. While some metrics are inherently redundant because they are alternate ways of representing the same basic information, metrics that are empirically redundant may provide useful information about aspects of the landscape under observation that are statistically correlated (Leitao et al. 2006, McGarigal et al. 2002).

Leitao et al. (2006) propose a core-set of ten metrics, selected to maximize landscape pattern description while minimizing redundancy, and to serve the typical needs of planners and managers. I used the Percentage of Landscape (PLAND) version of Class Area Proportion, and because the field landscapes are different sizes, Patch Density (PD) instead of Number of Patches. Most of these metrics can be applied at both the class and landscapelevels, however, PLAND is only available at the class-level, and Contagion (CONTAG) and Patch Richness (PR) are only available at the landscape-level. To calculate a class-level version of the Contagion index, I add the Clumpiness Index (CLUMPY) to the suite proposed by Leitao et al. (2006) resulting in 9 landscape-level metrics, and 9 class-level metrics calculated for each habitat type (Table 5). Patch-based metrics, Mean Patch Size (AREA), Radius of Gyration (GYRATE), Shape (SHAPE), Proximity (PROX), Euclidean Nearest 
Neighbor (ENN), and Edge Contrast (ECON), were calculated using an area weighted mean (AM). Because patch size is an important controlling factor of the composition, configuration, and function of landscapes, AM estimates the disproportionate ecological importance of larger patches (Leitao et al. 2006). In this study, the use of AM addresses the assumption that large patches of habitat likely contain more nests than small patches. At the class-level, AM multiplies the metric by the proportional abundance of the individual patch area to the total class area. At the landscape-level, AM multiplies the metric by the proportional abundance of the individual patch area to the total area of the landscape. Metrics were calculated for all habitat types to create a dataset useful for research beyond this study. Class-level metrics for the wetland habitat types where nests were found, emergent marsh (EM), wet meadow (WM), and dry meadow (DM), were evaluated in this study.

Table 5. Landscape metric descriptions (Leitao et al. 2006, McGarigal et al. 2002).

\begin{tabular}{|c|c|c|c|c|c|}
\hline Metric & Property & Aspect & Class & Landscape & Description (units) \\
\hline Patch Richness (PR) & Composition & Diversity & & $\mathrm{x}$ & Number of different patch types (count) \\
\hline $\begin{array}{l}\text { Percentage of Landscape } \\
\text { (PLAND) }\end{array}$ & Composition & Area/density/edge & $\mathrm{x}$ & & Proportion of landscape of a particular class (percent) \\
\hline Patch Density (PD) & Configuration & Area/density/edge & $\mathrm{x}$ & $\mathrm{x}$ & Density of patches in landscape or of a particular class (count / 100 hectares) \\
\hline Mean Patch Size (AREA_AM) & Configuration & Area/density/edge & $\mathrm{x}$ & $\mathrm{x}$ & $\begin{array}{l}\text { Area-weighted average size of patches in landscape or of a particular class } \\
\text { (hectares) }\end{array}$ \\
\hline $\begin{array}{l}\text { Radius of Gyration } \\
\text { (GYRATE_AM) }\end{array}$ & Configuration & Area/density/edge & $\mathrm{x}$ & $x$ & $\begin{array}{l}\text { Area-weighted average patch compaction of all in landscape or of a } \\
\text { particular class (meters) }\end{array}$ \\
\hline Shape (SHAPE_AM) & Configuration & Shape & $\mathrm{x}$ & $x$ & $\begin{array}{l}\text { Area-weighted average shape complexity of patches in landscape or of a } \\
\text { particular class (unitless, range }>=1 \text { ) }\end{array}$ \\
\hline Proximity (PROX_AM) & Configuration & Isolation/proximity & $\mathrm{x}$ & $\mathrm{x}$ & $\begin{array}{l}\text { Area-weighted average isolation within a search radius of a patch of a } \\
\text { particular class or all in landscape (unitless, range }>=0 \text { ) }\end{array}$ \\
\hline $\begin{array}{l}\text { Euclidian Nearest Neighbor } \\
\text { Distance (ENN_AM) }\end{array}$ & Configuration & Isolation/proximity & $\mathrm{x}$ & $x$ & $\begin{array}{l}\text { Area-weighted average Euclidian distance between each patch and its } \\
\text { nearest neighbor of a particular class or any in landscape (meters) }\end{array}$ \\
\hline Edge Contrast (ECON_AM) & Configuration & Contrast & $x$ & $x$ & $\begin{array}{l}\text { Area-weighted average contrast of neighboring patches for patches of a } \\
\text { particular class or all in a landscape (percent) }\end{array}$ \\
\hline Contagion (CONTAG) & Configuration & Contagion/interspertion & & $\mathrm{x}$ & Clumpiness of like patches, for all classes, across landscape (percent) \\
\hline Clumpiness Index (CLUMPY) & Configuration & Contagion/interspertion & $\mathrm{x}$ & & $\begin{array}{l}\text { Clumpiness of like patches, for single class, across landscape (unitless, range - } \\
1 \text { to 1) }\end{array}$ \\
\hline
\end{tabular}


Setting run parameters for FRAGSTATS software includes constructing a class properties file to specify the class names within the raster map, status as background (external only) or borders (none), and whether or not to include each class in the output (Table 6). The analysis type was set to standard and the 8-cell rule is used to consider adjacent cells as part of the same patch. A search distance radius of $30 \mathrm{~m}$ is specified for PROX_AM. Thirty meters was selected to eliminate any patch greater than the distance of one diagonal cell size away from the focal patch as being proximate. An edge weight file was created for use with ECON_AM (Table 7). All wetland habitat pairs are assigned a weight of zero (no contrast) and all wetland-habitat to non-wetland habitat pairs are assigned a weight of one (maximum contrast), as is the external background of the raster map that represents a neighboring Refuge field or off-refuge land.

Table 6. FRAGSTATS Class Properties File.

\begin{tabular}{cccc}
\hline ClassID & ClassName & Status & isBackground \\
\hline 1 & Cold and Hot Springs & FALSE & FALSE \\
2 & Dry Meadow & TRUE & FALSE \\
3 & Dunes & FALSE & FALSE \\
4 & Emergent Marsh & TRUE & FALSE \\
5 & Open Water & TRUE & FALSE \\
6 & Lake Basin & FALSE & FALSE \\
7 & Lava Flows & FALSE & FALSE \\
8 & Moist/Wet Meadow & TRUE & FALSE \\
9 & Playa & FALSE & FALSE \\
10 & Public Use Area & TRUE & FALSE \\
11 & Riparian Shrub & TRUE & FALSE \\
12 & Riverine & TRUE & FALSE \\
13 & Sagebrush Lowlands & TRUE & FALSE \\
14 & Sagebrush Steppe & TRUE & FALSE \\
15 & Salt Desert Scrub & TRUE & FALSE \\
999 & Background & FALSE & TRUE \\
\hline
\end{tabular}


Table 7. FRAGSTATS Edge weights matrix.

\begin{tabular}{|c|c|c|c|c|c|c|c|c|c|c|c|c|c|c|c|c|c|}
\hline & $F$ & 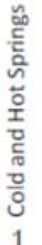 & 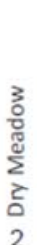 & $\begin{array}{l}\tilde{y} \\
\text { 苟 } \\
3 \\
3\end{array}$ & 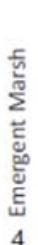 & 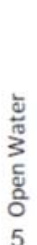 & 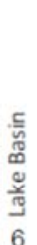 & $\begin{array}{l}\frac{n}{3} \\
\frac{0}{4} \\
10 \\
03 \\
7\end{array}$ & 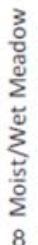 & $\frac{\sum_{0}^{0}}{\frac{10}{2}}$ & 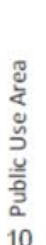 & 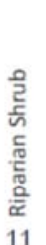 & 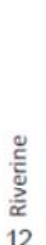 & 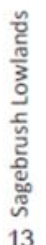 & 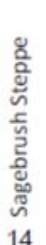 & 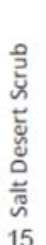 & 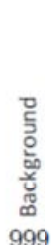 \\
\hline Cold and Hot Springs & 1 & 0 & 0 & 1 & 0 & 0 & 0 & 1 & 0 & 1 & 1 & 0 & 0 & 1 & 1 & 1 & 1 \\
\hline Dry Meadow & 2 & 0 & 0 & 1 & 0 & 0 & 0 & 1 & 0 & 1 & 1 & 0 & 0 & 1 & 1 & 1 & 1 \\
\hline Dunes & 3 & 1 & 1 & 0 & 1 & 1 & 1 & 0 & 1 & 0 & 0 & 1 & 1 & 0 & 0 & 0 & 1 \\
\hline Emergent Marsh & 4 & 0 & 0 & 1 & 0 & 0 & 0 & 1 & 0 & 1 & 1 & 0 & 0 & 1 & 1 & 1 & 1 \\
\hline Open Water & 5 & 0 & 0 & 1 & 0 & 0 & 0 & 1 & 0 & 1 & 1 & 0 & 0 & 1 & 1 & 1 & 1 \\
\hline Lake Basin & 6 & 0 & 0 & 1 & 0 & 0 & 0 & 1 & 0 & 1 & 1 & 0 & 0 & 1 & 1 & 1 & 1 \\
\hline Lava Flows & 7 & 1 & 1 & 0 & 1 & 1 & 1 & 0 & 1 & 0 & 0 & 1 & 1 & 0 & 0 & 0 & 1 \\
\hline Moist/Wet Meadow & 8 & 0 & 0 & 1 & 0 & 0 & 0 & 1 & 0 & 1 & 1 & 0 & 0 & 1 & 1 & 1 & 1 \\
\hline Playa & 9 & 1 & 1 & 0 & 1 & 1 & 1 & 0 & 1 & 0 & 0 & 1 & 1 & 0 & 0 & 0 & 1 \\
\hline Public Use Area & 10 & 1 & 1 & 0 & 1 & 1 & 1 & 0 & 1 & 0 & 0 & 1 & 1 & 0 & 0 & 0 & 1 \\
\hline Riparian Shrub & 11 & 0 & 0 & 1 & 0 & 0 & 0 & 1 & 0 & 1 & 1 & 0 & 0 & 1 & 1 & 1 & 1 \\
\hline Riverine & 12 & 0 & 0 & 1 & 0 & 0 & 0 & 1 & 0 & 1 & 1 & 0 & 0 & 1 & 1 & 1 & 1 \\
\hline Sagebrush Lowlands & 13 & 1 & 1 & 0 & 1 & 1 & 1 & 0 & 1 & 0 & 0 & 1 & 1 & 0 & 0 & 0 & 1 \\
\hline Sagebrush Steppe & 14 & 1 & 1 & 0 & 1 & 1 & 1 & 0 & 1 & 0 & 0 & 1 & 1 & 0 & 0 & 0 & 1 \\
\hline Salt Desert Scrub & 15 & 1 & 1 & 0 & 1 & 1 & 1 & 0 & 1 & 0 & 0 & 1 & 1 & 0 & 0 & 0 & 1 \\
\hline Background & 999 & 1 & 1 & 1 & 1 & 1 & 1 & 1 & 1 & 1 & 1 & 1 & 1 & 1 & 1 & 1 & 1 \\
\hline
\end{tabular}

\section{Landscape Metrics per Field}

Nine landscape-level metrics and nine class-level metrics for each wetland nesting habitat type were calculated for 48 fields resulting in 36 total metrics (Table 8). The landscape metrics include all habitats in their calculation. The playa habitat type did not occur in any fields with a calculated survival type. The emergent marsh (EM) and dry meadow (DM) habitats are not present in all 48 fields resulting in a lower sample size. The Euclidean Nearest Neighbor (ENN) metrics has more missing data values than the other metrics for each wetland habitat class. This occurs when there is only one patch of that particular class within the landscape $(\mathrm{NP}=1)$. 
Table 8. Summary statistics of landscape pattern metric for 48 fields. LAND prefixes the landscape-level metrics EM for class-level emergent marsh habitat, WM for wet meadow, and DM for dry meadow (See Table 5 for the descriptions of the metrics).

\begin{tabular}{|c|c|c|c|c|c|c|c|c|c|}
\hline Variable & $n$ & Mean & Median & Variance & Stdev & Min & Max & Range & Missing \\
\hline$\overline{\text { LAND_PR }}$ & 48 & 6.35 & 7 & 3.89 & 1.97 & 3 & 10 & 7 & 0 \\
\hline LAND_PD & 48 & 32.84 & 34.58 & 274.45 & 16.57 & 2.03 & 64.24 & 62.2 & 0 \\
\hline LAND_AREA_AM & 48 & 86.22 & 62.18 & 2922.62 & 54.06 & 13.23 & 233.19 & 219.97 & 0 \\
\hline LAND_GYRATE_AM & 48 & 420.57 & 388.16 & 16418.81 & 128.14 & 151.53 & 711.44 & 559.91 & 0 \\
\hline LAND_SHAPE_AM & 48 & 3.45 & 3.48 & 1.15 & 1.07 & 1.14 & 6.07 & 4.93 & 0 \\
\hline LAND_PROX_AM & 48 & 156.8 & 9.37 & 324220.2 & 569.4 & 0 & 3874.43 & 3874.43 & 0 \\
\hline LAND_ENN_AM & 48 & 70.43 & 49.46 & 3746.72 & 61.21 & 0 & 300.16 & 300.16 & 0 \\
\hline LAND_ECON_AM & 48 & 29.79 & 25.1 & 546.84 & 23.38 & 0 & 78.81 & 78.81 & 0 \\
\hline LAND_CONTAG & 48 & 66.11 & 64.93 & 102.54 & 10.13 & 42.07 & 98.99 & 56.92 & 0 \\
\hline EM_PLAND & 43 & 27.78 & 27.81 & 362.86 & 19.05 & 0.03 & 71.48 & 71.45 & 5 \\
\hline EM_PD & 43 & 5.72 & 3.33 & 45.1 & 6.72 & 0.12 & 34.58 & 34.46 & 5 \\
\hline EM_AREA_AM & 43 & 59.78 & 34.67 & 7236.93 & 85.07 & 0.08 & 386.88 & 386.8 & 5 \\
\hline EM_GYRATE_AM & 43 & 338.08 & 293.66 & 66803.51 & 258.46 & 11.99 & 1136.91 & 1124.91 & 5 \\
\hline EM_SHAPE_AM & 43 & 3.46 & 2.79 & 5.41 & 2.33 & 1 & 10.74 & 9.74 & 5 \\
\hline EM_PROX_AM & 43 & 57.15 & 0 & 44294.44 & 210.46 & 0 & 1077.1 & 1077.1 & 5 \\
\hline EM_ENN_AM & 39 & 76 & 51.74 & 3679.91 & 60.66 & 20.01 & 301.36 & 281.35 & 9 \\
\hline EM_ECON_AM & 43 & 15.65 & 6.31 & 402.67 & 20.07 & 0 & 73.08 & 73.08 & 5 \\
\hline EM_CLUMPY & 43 & 0.91 & 0.92 & 0 & 0.06 & 0.58 & 1 & 0.42 & 5 \\
\hline WM_PLAND & 48 & 46.25 & 49.83 & 601.5 & 24.53 & 0.06 & 98.34 & 98.28 & 0 \\
\hline WM_PD & 48 & 4.94 & 4.49 & 13.23 & 3.64 & 0.6 & 17.94 & 17.34 & 0 \\
\hline WM_AREA_AM & 48 & 76.73 & 60.47 & 4579.93 & 67.68 & 0.09 & 243.59 & 243.5 & 0 \\
\hline WM_GYRATE_AM & 48 & 398.37 & 382.12 & 37488.58 & 193.62 & 22.22 & 880.73 & 858.51 & 0 \\
\hline WM_SHAPE_AM & 48 & 3.68 & 3.39 & 2.04 & 1.43 & 1.35 & 7.56 & 6.21 & 0 \\
\hline WM_PROX_AM & 48 & 66.49 & 3.07 & 31371.77 & 177.12 & 0 & 1037.29 & 1037.29 & 0 \\
\hline WM_ENN_AM & 45 & 47.78 & 32.68 & 1117.76 & 33.43 & 20 & 170.29 & 150.29 & 3 \\
\hline WM_ECON_AM & 48 & 26.81 & 24.63 & 483.95 & 22 & 0 & 84.95 & 84.95 & 0 \\
\hline WM_CLUMPY & 48 & 0.88 & 0.88 & 0 & 0.05 & 0.67 & 0.98 & 0.31 & 0 \\
\hline DM_PLAND & 24 & 10.84 & 2.67 & 522.52 & 22.86 & 0.01 & 99.78 & 99.76 & 24 \\
\hline DM_PD & 24 & 1.77 & 0.78 & 6.32 & 2.51 & 0.29 & 11.33 & 11.05 & 24 \\
\hline DM_AREA_AM & 24 & 19.78 & 2.91 & 1696.65 & 41.19 & 0.04 & 152.1 & 152.06 & 24 \\
\hline DM_GYRATE_AM & 24 & 183.6 & 120.06 & 32309.18 & 179.75 & 14.14 & 713.9 & 699.75 & 24 \\
\hline DM_SHAPE_AM & 24 & 2.42 & 2.03 & 1.5 & 1.22 & 1.14 & 5.71 & 4.57 & 24 \\
\hline DM_PROX_AM & 24 & 0.65 & 0 & 3.13 & 1.77 & 0 & 8.2 & 8.2 & 24 \\
\hline DM_ENN_AM & 14 & 244.02 & 173.79 & 71193.19 & 266.82 & 22.36 & 967.39 & 945.03 & 34 \\
\hline DM_ECON_AM & 24 & 16.64 & 0 & 759.64 & 27.56 & 0 & 84.06 & 84.06 & 24 \\
\hline DM_CLUMPY & 24 & 0.82 & 0.92 & 0.16 & 0.4 & -1 & 0.97 & 1.97 & 24 \\
\hline
\end{tabular}

\section{Data Analysis}

Multi-variate regression can determine which set of independent variables best explains the variability in a dependent variable, however, the method requires a minimum sample-size to retain statistical power. Green (1991) suggests the rule-of-thumb formula $\mathrm{N}=$ 
$50+8 \mathrm{~m}$ where $\mathrm{m}=$ the number of predictors, is accurate for studies with 7 or less predictors. My arbitrary minimum nest sample size of 5 resulted in a total of 48 fields available and below the minimum of 58 as per Green's (1991) rule-of thumb. Following Hensler and Nichols' (1981) minimum sample size of 20 nests for survival estimation would have resulted in only 18 fields available for analysis, far below the minimum required sample size for regression with multiple predictors. Unfortunately, the more species and years pooled to meet these minimum sample size requirements, the more subject the estimation is to the issues associated with biological and temporal assumptions. Further, inclusion of all calculated metrics in multiple regression analysis would result in a sample size of 24 because dry meadow is not present in all fields. For this reason, I used the univariate Pearson R correlation analysis method to individually assess the relationships among landscape pattern metrics and the potential influence of landscape variables upon duck nest success.

Correlation matrices for each set of landscape metrics were developed using $\mathrm{R}$ statistical software (R Development Core Team 2008). The graphical matrix provides a histogram of the variables along the diagonal, a scatterplot with an ordinary least squares (OLS) best-fit line for each pair-wise combination below the diagonal, and the corresponding coefficient of correlation (r) value above. The tabular matrix shows the r-values below the diagonal and corresponding significance $(\mathrm{p})$ value above.

The coefficient of correlation (r) provides a measure of strength and direction of association between variables (Rogerson 2006). I examined the pair-wise associations between Rate and landscape metrics, as well as between landscape metrics, to assess redundancy among the dataset. Significance values (p) determine the probability with which 
the correlation is real and to not have occurred by chance (Rogerson 2006). Scatterplots of pair-wise relationships were used to assess the shape, or linearity of relationships among variables. Histograms were used to assess normality and appropriate transformation to remedy non-normal variables. Both graphics provided information about the presence of outliers. Transformation of the non-normal variables reduces the effect of outliers and may provide a better indication of a significant relationship (McDonald 2009). The log-transformation for positively skewed data, and the square-transformation for negatively skewed data were used, with the addition of a constant, 1, when zeros are present in the data.

While correlation does not determine causation, it provides information for assessing the potential relationship among variables. Positive relationships, where the variable Rate plotted on the Y-axis, increases with increasing value of the landscape variable plotted on the $\mathrm{X}$-axis, are quantified with a positive r-value. Negative relationships, where Rate decreases with an increase in the landscape variable, are quantified as negative r-values. I consider correlation between landscape metrics and nest success to be statistically significant when the p-value is less than the commonly accepted level of 0.05 .

Association between Survival Rate and Landscape Variables

I determined the distribution of survival rate among fields to be random by testing for spatial autocorrelation, Moran's $\mathrm{I}=-0.09, \mathrm{p}=0.45$. The frequency distribution of Rate is slightly skewed to the right (Figure 5). Log transformation results in an outlier because the lowest rate is 0.00 for the Grain Field. The untransformed data appears to yield the nearest normal distribution suitable for analysis. 

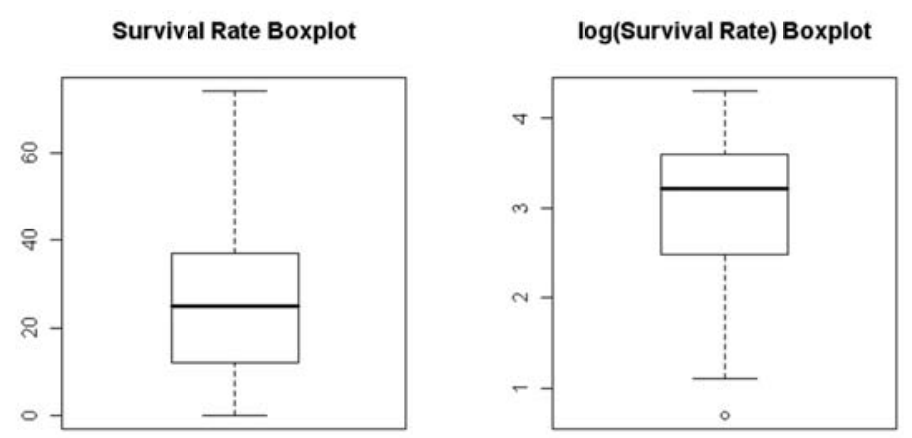

Figure 5. Boxplots of Survival Rate and log transformation of Rate.

I examined scatterplots and correlation values for all pairs of variables to evaluate the statistical relationship between survival rate and potentially explanatory landscape indices, and among landscape indices. Many of the metrics did not show significant correlations with nesting data (Table 9, see Appendix for the complete graphical correlation matrices).

Landscape-level metrics were calculated for all 48 fields. The absolute Pearson R correlation values, and significance, of the landscape-level metrics range from $\mathrm{r}=0.06, \mathrm{p}=$ .69, to $r=0.33, p=.02$ (Table 9). Only Patch Richness $(P R)$ of landscape has a correlation, $r$ $=0.33, \mathrm{p}=0.02$, at a commonly accepted statistically significant level, $\mathrm{p}<0.05$ (Figure 6).

Class-level metrics for Emergent Marsh (EM) habitat were calculated for the 43 fields where it is present, except for the metric ENN, which was calculated for only 39 fields having more than one EM patch (Table 8). No calculated correlations between EM class-level metrics and Rate are statistically significant at a commonly accepted level, p < 0.05 (Table 9). 
Table 9. Landscape and class-level metrics correlation (r) and significance (p) values with Rate.

\begin{tabular}{|c|c|c|c|c|c|}
\hline Metric & $r$ & $\mathrm{p}$ & Metric & $\mathrm{r}$ & $\mathrm{p}$ \\
\hline Landscape-level & & & Wet Meadow Class-level & & \\
\hline LAND_PR & 0.33 & 0.02 & WM_PLAND & 0.10 & 0.50 \\
\hline LAND_PD & 0.10 & 0.51 & log(WM_PD) & 0.06 & 0.70 \\
\hline LAND_AREA_AM & 0.06 & 0.67 & WM_AREA_AM & 0.31 & 0.03 \\
\hline LAND_GYRATE_AM & 0.06 & 0.69 & WM_GYRATE_AM & 0.30 & 0.04 \\
\hline LAND_SHAPE_AM & 0.11 & 0.48 & WM_SHAPE_AM & 0.31 & 0.03 \\
\hline log(LAND_PROX_AM+1) & -0.06 & 0.66 & $\log ($ WM_PROX_AM+1) & -0.09 & 0.55 \\
\hline LAND_ENN_AM & 0.16 & 0.27 & $\log ($ WM_ENN_AM) & -0.03 & 0.86 \\
\hline LAND_ECON_AM & -0.07 & 0.65 & WM_ECON_AM & 0.07 & 0.62 \\
\hline LAND_CONTAG & -0.07 & 0.66 & WM_CLUMPY^2 & 0.20 & 0.18 \\
\hline Emergent Marsh Class-level & & & Dry Meadow Class-level & & \\
\hline EM_PLAND & -0.02 & 0.89 & $\log ($ DM_PLAND) & -0.05 & 0.80 \\
\hline $\log \left(E M \_P D\right)$ & -0.21 & 0.18 & $\log \left(\mathrm{DM} \_\mathrm{PD}\right)$ & 0.49 & 0.02 \\
\hline $\log (E M$ EAREA_AM) & 0.03 & 0.85 & $\log \left(D M \_A R E A \_A M\right)$ & -0.20 & 0.35 \\
\hline Iog(EM_GYRATE_AM) & 0.02 & 0.92 & log(DM_GYRATE_AM) & -0.11 & 0.61 \\
\hline $\log \left(E M \_S H A P E \_A M\right)$ & 0.03 & 0.84 & $\log (\mathrm{DM}$ _SHAPE_AM) & 0.08 & 0.70 \\
\hline $\log (E M$ EROX_AM+1) & 0.02 & 0.92 & $\log \left(D M \_P R O X \_A M+1\right)$ & 0.19 & 0.36 \\
\hline $\log \left(E M \_E N N \_A M\right)$ & -0.15 & 0.37 & $\log \left(D M \_E N N \_A M\right)$ & 0.09 & 0.77 \\
\hline $\log \left(E M \_E C O N \_A M+1\right)$ & 0.00 & 0.99 & $\log \left(\mathrm{DM} \_\right.$ECON_AM+1) & -0.25 & 0.23 \\
\hline EM_CLUMPY^2 & 0.06 & 0.71 & DM_CLUMPY^3 & 0.10 & 0.64 \\
\hline
\end{tabular}

\section{Landscape-level Metrics}

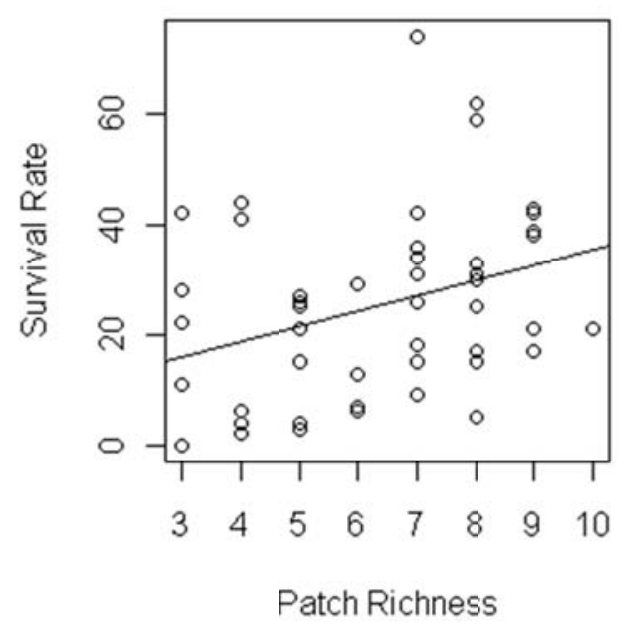

Figure 6. Scatterplot and regression line for Rate $\sim$ landscape-level metric Patch Richness (PR). 
Class-level metrics for Wet Meadow (WM) habitat were calculated for all 48 fields, except for the metric ENN, which was calculated for only 45 fields having more than one WM patch (Table 8). The absolute Pearson R correlation values, and significance, of the WM class-level metrics range from $\mathrm{r}=0.03, \mathrm{p}=.86$, to $\mathrm{r}=0.31, \mathrm{p}=.03$ (Table 9). Calculated correlations for the metrics Mean Patch Size (AREA), $r=0.31, p=0.03$, Radius of Gyration (GYRATE), $r=0.30, p=0.04$, and Shape Index $($ SHAPE $), r=0.31, p=0.03$, are all statistically significant at a commonly accepted level, $\mathrm{p}<0.05$ (Figure 7).
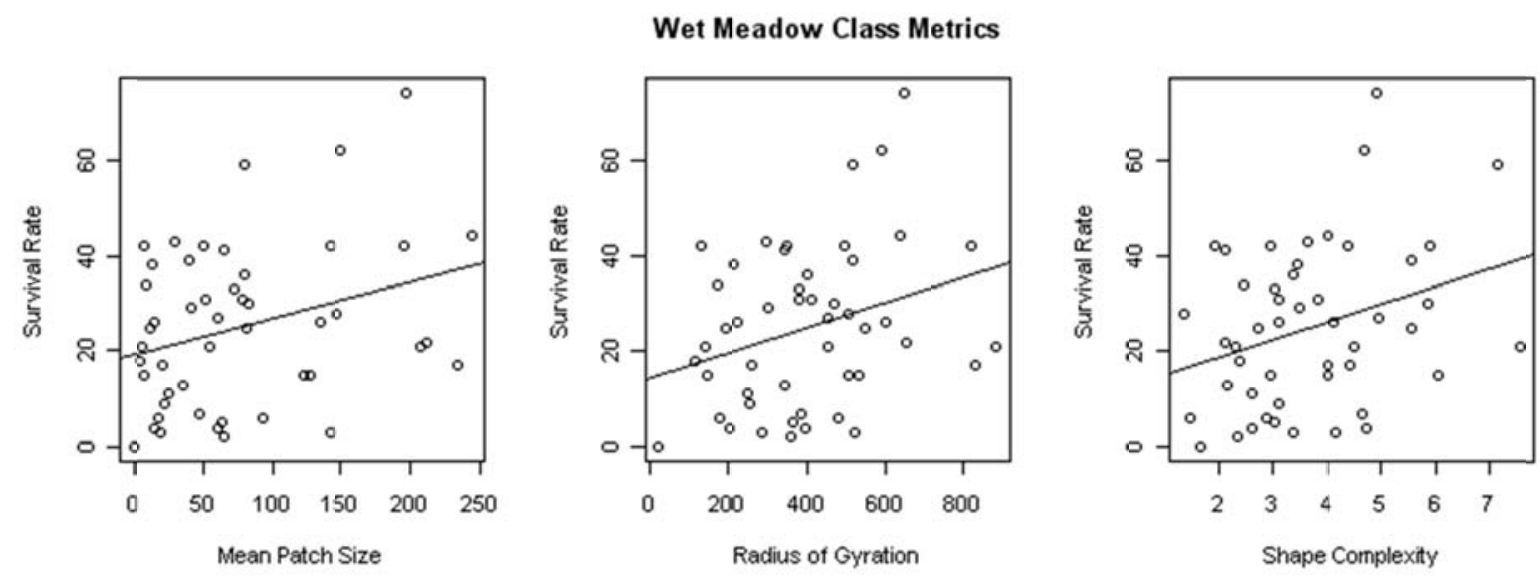

Figure 7. Scatterplots and regression lines for Rate $\sim$ wet meadow class-level metrics Mean Patch Size (AREA), Radius of Gyration (GYRATE), and Shape (SHAPE).

The three wet meadow (WM) metrics having significant relationships with Rate are inter-correlated. Radius of Gyration (GYRATE) is most related to Mean Patch Size (AREA), $\mathrm{r}=0.92, \mathrm{p}<0.01$, when all patches are most compact. It follows that the cell furthest from the centroid in an individual patch would be greater for larger patches than smaller ones.

GYRATE is also correlated with the Shape Index (SHAPE), $r=0.63, p<0.01$. It similarly follows that the more complex a shape, the greater the radius of gyration. The lower strength 
correlation between AREA and SHAPE, $\mathrm{r}=0.40, \mathrm{p}=0.01$, reveals they may vary more independently of each other, though when they both increase, so will the Radius of Gyration.

Class-level metrics for Dry Meadow (DM) habitat were calculated for the 24 fields where it is present, except for the metric ENN, which was calculated for only 14 fields having more than one DM patch (Table 8). The absolute correlation values, and significance, of the DM class-level metrics range from $r=0.05, p=.80$, to $r=0.49, p=.02$ (Table 9). Calculated correlation for the log transformation of Patch Density (PD), $r=0.49, p=0.02$, is statistically significant at a commonly accepted level, $\mathrm{p}<0.05$ (Figure 8). The fields associated with the cluster of points plotted between 0 and 7 rate, and -0.51 and 0.04 PD, are spatially disaggregated across the Refuge.

\section{Dry Meadow Class Metrics}

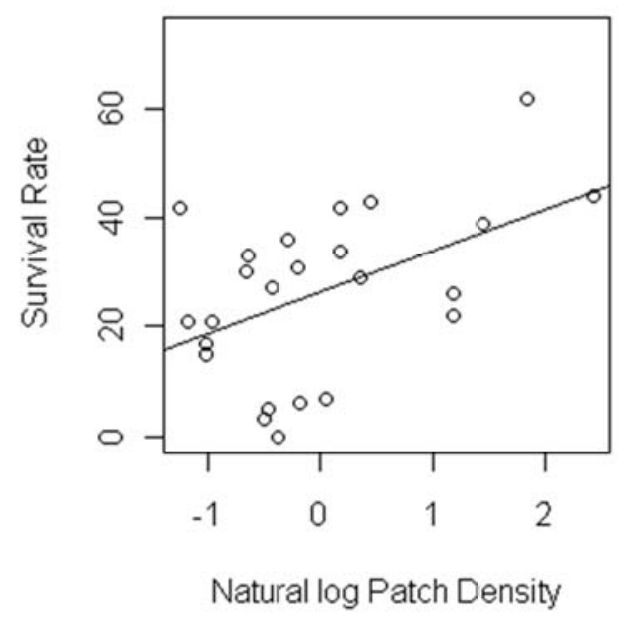

Figure 8. Scatterplot and regression line for Rate $\sim$ dry meadow class-level metric Patch Density (PD). 


\section{DISCUSSION}

This study explored the influence of actively managed wetland landscape structure on

duck nest success, to build upon the explanatory results of past studies, and provide insight to design implications for refuges. Based on correlation analysis of survival rate with landscape pattern metrics calculated from a habitat map, several potential nest success-landscape relationships may exist (Figure 9). Of the 36 metrics evaluated, Landscape Patch Richness (LAND_PR); Wet Meadow Shape (WM_SHAPE_AM), Mean Patch Size (WM_AREA_AM), and Radius of Gyration (WM_GYRATE_AM); and Dry Meadow Patch Density (DM_PD), are the most statistically significant, $\mathrm{p}<0.05$, and have the strongest correlations, $\mathrm{r}>=0.30$.

\section{Biogeographical Relevance}

The landscape-level metric patch richness is a count of all habitat types within a landscape. The median is 7 with a range of 3 to 10 (Table 8). My results show that as the habitats within a field become more diverse, nest success increases. Examining a sample of the fields with the highest patch richness and highest survival rate, most of the fields are on the periphery of the Blitzen Valley where there are more upland habitat types. Diversity within a field may be unattractive to predators because they are not a likely location to find a meal, or a deterrent if the habitat class Public Use Area is present. My literature review of past studies did not reveal a relationship between avian productivity and habitat diversity. Analysis 
of landscape patch richness interaction with other class-level metrics for influence on survival rate may reveal more relevant interpretations.

The class-level metrics for emergent marsh habitat revealed no statistically significant relationships. Tall dense emergent vegetation is the characteristic plant community of many wetland habitats, often the most proximate to open water, and provides a maximum amount of nesting cover. The lack of relationship may be because of the high number of dabbling ducks $(n=1080)$ recorded in the dataset opposed to divers $(n=195)$. Diving ducks are restricted to habitat in close proximity to open water because of the distance required for flight take-offs and landings (Bellrose 1980). This habitat most often will be emergent marsh in a wetland complex environment. Dabbling ducks, however, are more likely to nest in meadow habitats as they can walk, take-off and land from a standing position on land unlike divers (Bellrose 1980). The difference in amount of dabbling and diving ducks sampled may be a result of the access to and detectability of nests in different habitats.

Wet meadow is the only nesting habitat type found within all 48 fields included in this study. If the detection of duck nests with this data collection effort is an indication of nesting habitat preference among duck species, than it is reasonable that the wet meadow habitat type is important to nest success. The influence of habitat patch size to duck productivity has been discovered in previous studies by Fairbairn and Dinsmore (2001), Horn et al. (2005), and Nudds (1992). The positive correlation between mean patch size and rate in this study supports this relationship.

The relationship between avian productivity and shape complexity, however, is less understood (Riffell et al. 2001). The AREA and SHAPE metrics are significantly correlated, $\mathrm{r}$ 
$=0.40, \mathrm{p}=0.01$, so some explanation may be attributed to the size of the wet meadow patch. In impounded wetlands, complexity of the wet meadow habitat on the downhill side may benefit dabbling ducks as was found by Nilsson (1978). This complexity would result in increased length of edge between wet meadow and the emergent marsh-open water complex, providing escape from predators and access to aquatic foraging. In contrast, increased edge on the uphill side, between wet and dry meadows, would provide greater access to predators from upland habitats.

Radius of Gyration is a measure of patch extensiveness and was observed to be highly correlated with both mean patch size and shape complexity. An extensive patch of wet meadow may have more area, higher edge, or both which may contribute to increased nest success. Finally, nests in wet meadow may be less susceptible to abandonment because of flooding than those in emergent marsh, and may be less accessible to predators than nests in dry meadow. Analysis of plant community data within the nest dataset may corroborate this hypothesis.

The dry meadow class-level metric Patch Density (PD) represents a measure of fragmentation of patches within a field where an increase in PD results from more patches within a given area (McGarigal et al. 2002). My results show that as dry meadows become more fragmented, nest success increases. The values of dry meadow patch density within the Blitzen Valley and Double $\mathrm{O}$ areas are relatively low compared to the other habitat classes. The mean patch density for all habitat types is 32.84 , while the mean patch density for dry meadow is 1.77 patches/100 hectares (Table 8 ). Under normal circumstances, dry meadow would have a lower survival rate because of higher access by predators. This seems to be 
mitigated within the Blitzen Valley and Double $\mathrm{O}$ areas where fields with the highest patch density of dry meadow and highest survival rate have a fragmented spatial arrangement within a matrix of wet meadow (Figure 9). These fields may be correlated with area of habitat types that provide more nest cover. Fields with higher density of dry meadow patches are often not impounded wetlands and may be less susceptible to unplanned flooding and subsequent nest failure because of abandonment.

If these variables are biogeographically significant, it is only at this scale, at Malheur NWR for this time period, and for this set of duck data. Other metrics may be relevant at other scales at Malheur, and for other ground nesting birds. It is also likely that interactions between landscape variables are missed with this analysis. Any single landscape variable may not influence duck nest success, while in combination with others, they may be significant. It is also possible non-linear relationships exist between landscape indices and survival rate at Malheur NWR. In a study of duck nest success in the Prairie Pothole region of the U.S., Horn et al. (2005) discovered a non-linear relationship between nest success and wetland patch size. Non-linear relationships, however, are undetected by correlation analysis.

\section{Sample Size as an Explanatory Variable}

I assessed the tenuous associations between landscape indices and survival rate using a post-hoc examination of sample size as an explanatory variable (Figure 10). Sample size was $\log$ transformed to better approximate a normal distribution and make it easier to assess a relationship between variables. While not statistically significant $(\mathrm{p}=0.15)$, the correlation strength, $r=0.23$, is not much lower than the strongest values in this study. Fields with few 
nests may be more often located in landscapes more susceptible to predation and pressures of abndonment. Assuming all ducks select nesting habitat with the highest rates of success, for reasons of limited habitat availability and territoriality, a small number of ducks may be forced to nest is less than desireable habitat. If opportunity to find nests is related to the availability of nests, then this relationship may reveal that a more systematic amount of effort was placed on the survey of each field beyond what an opportuistic sampling strategy may imply.

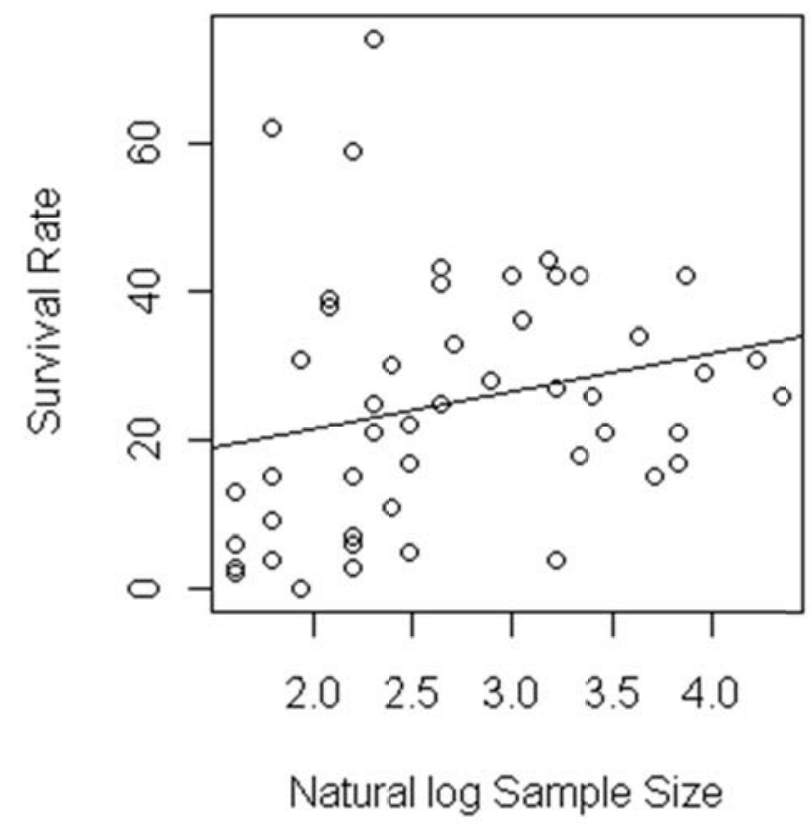

Figure 10. Scatterplot and regression line for Rate $\sim$ Sample Size.

\section{CONCLUSIONS}

This paper investigated the influence of the landscape structure of wetland habitat on nest success to reveal several significant relationships. The diversity of habitat types; area, 
extensiveness, and amount of edge of wet meadow; and the fragmentation of dry meadow within a management unit were all observed to positively influence duck nest success. Habitat preservation and enhancement is the most important tactic of waterfowl conservation (Bellrose 1980). The mean survival rate for duck nests pooled by field at Malheur NWR $1987-1998$ is $25 \% \pm 17 \%$ with a range of 0 to $74 \%$. This estimate is consistent with rates in the Prairie Pothole region of the U.S. 1966-1984 that ranged from $<5$ to $36 \%$ among sub-regions, sub-periods, and species (Klett et al. 1988). However, duck nest survival rates for fields with more than five nests in this study have a positively skewed distribution. Forty-five of 48 fields have a rate less than $50 \%$ with the remaining at 59, 62, and $75 \%$. An obvious management objective to maximize duck productivity, and subsequently that of other wetland ground nesting birds, would be to identify and replicate the actionable variables that positively influence nest success. One of these variables may be the structural design of wetland landscapes by altering the composition and configuration of habitat types. Landscape structure of wetlands is a manageable variable at wildlife refuges, while others such as duck behavior, surrogate prey populations, and the weather, are not. These findings may provide insight to the optimal design of artificial and restored wetlands to maximize nest success, the key variable in the population dynamics of many birds (Aebischer 1999).

This study also shows how established methods of estimating nest success, quantifying landscapes, and statistical analysis can be used with secondary data to assess general ideas about the influence of refuge landscapes on wildlife. Differences in spatial ecological patterns between landscapes can be difficult to quantify using visual map interpretation. At Malheur NWR, the reasons for the distribution of duck nest success across 
fields for the period 1987-1998 are not entirely apparent by visual map interpretation. The field of landscape ecology provides a quantitative approach for assessing the potential influence of pattern on process with the use of spatial metrics derived from maps.

Nest success has been partially explained by other habitat variables (Ivey and Dugger 2008), yet there has been support among the scientific community to evaluate the effect of spatial context (Naugle et al. 1999). Landscape effects have been studied for their influence on wetland avian species presence/absence data, however, Riffell et al. (2003) suggest including nest success to enhance these bird productivity studies. The findings of this paper compliment past nest-success-studies by lending a landscape perspective, and compliment past landscape-studies of wetland bird productivity by adding the reproductive component of nest success.

\section{Assumptions and Issues of Scale}

This study was limited in a number of ways and caution should be applied to evaluating the applicability of these results. The small sample-size limited the analysis to univariate statistical analysis that does not account for the interaction among explanatory landscape variables. While sample sizes are often increased by pooling species, study areas, or time periods, this may lead to erroneous results if the data sets that are pooled actually differ (Johnson and Shaffer 1990). The behavioral nest site selection preferences of duck species may preclude the assumption for pooling species when calculating survival rate within a field (Weller 1999). While predators may not discriminate among duck species, an individual species habitat preference may dispose them to more or less access by predators. 
Additionally, different habitat types may be more or less susceptible to events influencing abandonment such as flooding. Separating dabbling ducks, more likely to be meadow nesters, and diving ducks, obligate near water nesters (Bellrose 1980), or calculating survival rates by habitat type when included in the field data, may yield more relevant results for class-level metrics.

While objective habitat may not change over the time scale studied, the quality of plant communities and abundance of seasonal open water within each field resulting from management actions may persist on the landscape for several years. The spread of invasive species, such as reed canary grass (Phalaris arundinacea) and perennial pepperweed (Lepidium latifolium), have rendered large areas of fields to be non-habitat and is not categorized in the objective habitat planning map. Calculating landscape metrics from a remotely sensed land-cover map, tested to be representative for the time period under observation, may yield more relevant results. Further, the 11 year period used in this study may not be adequate to reduce bias of inter-annual variables such as weather, surrogate prey populations, and predator control practices. The importance of these variables within a short time period likely reduces the detectable effect of landscape patterns.

The scale at which landscape metrics are calculated is of paramount importance to the relevance of landscape ecological studies (Wiens 1989). Addicott et al. (1987) suggest the elements of scale, grain and extent, should be established relative to an organism's perception and response to the environment. The spatial grain of the habitat map used in this study, and the categorical scale of habitat types, does not include potentially important corridors and barriers to predators such as dikes, roads, and irrigation ditches that may influence nest 
success within an individual patch. Class-level metrics for these land-cover categories within a field may yield significant results as potential influences to nest success. The habitat map includes riparian shrub, riverine, and open water classes that are not nesting habitat, however, are part of the wetland complex within the upland matrix. I accounted for these habitat types by assigning zero edge contrast between these and the nesting habitat classes for the edge contrast index (ECON). These classes, however, often fragment nesting habitat classes and affect calculations of their shape complexity and patch density, further reducing the ability to detect an effect of the complete wetland complex. Finally, I chose the extent of the landscapes to be relevant to Refuge management though I examined relationships between landscape pattern variables with a vital rate influenced by ecological processes. The scales at which ecological processes occur that influence nest success are likely at a different extent than the management field boundary.

\section{Recommended Study}

While this study revealed statistically significant results, the ability to appropriately pool data for species is necessary to further study spatial differences between landscapes. The availability of more historical data and continued monitoring may provide the sample sizes required to justify necessary assumptions and better assess the effect of influential variables. A larger dataset would support estimating survival rate for dabbling and diving ducks separately to reduce issues with assumptions of pooling species. This would allow testing differences in abandonment and predation rates among groups of species. Data for other ground nesting waterfowl such as Canada Geese (Branta canadensis) may be included to 
further increase sample size for meadow habitats. The most appropriate segregation of nest data for survival estimation, however, would be to pool nests by habitat type when collected with the field data.

Including roads and dikes in the land-cover map would also help account for habitat fragmentation and access by predators. Spatially merging all wetland habitat types to assess class-level indices about a single wetland habitat class within a matrix of non-nesting landcover would allow more direct comparison to previous studies. Further, to better match scale to the relevant ecological processes, the extent could be systematically increased by buffering field boundaries.

Using individual raster maps for each field to represent discrete landscapes is problematic since habitats do not always stop at the field boundary. Including a field border in the raster map that categorizes the boundary as refuge or off-refuge may alleviate some of this problem. When selecting metrics, the mean $(\mathrm{MN})$ of patch based metrics with measurable units may provide easier interpretation than area weighted mean (AM). The Proximity (PROX) index could be calculated using a systematically increasing search distance for the potential to detect a significant relationship. Though this study was restricted to class and landscape-level analysis, coordinate data of nest locations should be used to incorporate patch-level metrics when available. Alternately, because many fields are dominated by a single largest patch, it is reasonable to assume this is where the majority of duck nests would be found. Patch-level metrics could be calculated for each field and the largest patch size per field per class selected for analysis. Inclusion of a max patch size metric would approximate a patch-level assessment. 
Studies that assess objective habitat should consider the availability and quality of habitat during the time period under investigation. This information can be derived from historic remotely-sensed land-cover maps produced from freely available archival satellite imagery. Finally, future research about long-term averages of avian reproductive productivity should include brood success in addition to nest success. These recommendations may help future research about the effect of landscape structure on avian productivity, a subject that will remain important to understanding how refuge design and management may best protect these resources. 


\section{REFERENCES}

Addicott, J.F., J.M. Aho, M.F. Antolin, D.K. Padilla, J.S. Richardson, and D.A. Soluk. 1987. Ecological neighborhoods: scaling environmental patterns. OIKOS. 49:340-346.

Aebischer, N.J. 1999. Multi-way comparisons and generalized linear models of nest success: Extensions of the Mayfield method. Bird Study. 46(supplement):22-31.

Baldassare, G.A. and E.G. Bolen. 1994. Waterfowl Ecology and Management. New York, NY: John Wiley and Sons, Inc.

Bellrose, F.C. 1980. Ducks, Geese \& Swans of North America. 3rd edition. Harrisburg, PA: Stackpole Books.

Cornely, J.E. 1982. Waterfowl Production at Malheur National Wildlife Refuge, 1942-1980. Transactions of the Forty-seventh North American Wildlife and Natural Resources Conference, ed. Kenneth Sabol. Washington, DC.

Cowardin, L.M., V. Carter, F.C. Golet, and E.T. LaRoe. 1979. Classification of wetlands and deepwater habitats of the United States. U. S. Department of the Interior, Fish and Wildlife Service, Washington, D.C.

EPA. 2009. Wetlands Fact Sheets. Environmental Protection Agency. Last accessed March 10, 2009. http://www.epa.gov/OWOW/wetlands/facts/contents.html.

Fairbairn S.E., and J.J. Dinsmore. 2001. Local and landscape level influences on wetland bird communities of the Prairie Pothole Region of Iowa, U.S.A. Wetlands. 21(1):4147.

Forman, R.T.T. 1995. Land Mosaics: The Ecology of Landscapes and Regions. Cambridge, New York: Cambridge University Press.

Fredrickson, L.H. and T.S. Taylor. 1982. Management of seasonally flooded impoundments for wildlife. U.S. Dept. of the Interior, Fish and Wildlife Service, Washington, D.C.

Green, S.B. 1991. How many subjects does it take to do a regression analysis? Multivariate Behavioral Research. 26:499-510.

Guard, B.J. 1995. Wetland Plants of Oregon and Washington. Renton, Washington: Lone Pine Publishing. 
Hensler, G.L. and J.D. Nichols. 1981. The Mayfield method of estimating nesting success: A model, estimators and simulation results. 1981. Wilson Bulletin. 93(1)42-53.

Horn, D.J., M.L. Phillips, R.R. Koford, W.R. Clark, M.A. Sovada, and R.J. Greenwood. 2005. Landscape composition, patch size, and distance to edges: interactions affecting duck reproductive success. Ecological Applications. 15(4):1367-1376.

Ivey, G.L., J.E. Cornely, and B.D. Ehlers. 1998. Carp Impacts on Waterfowl at Malheur National Wildlife Refuge, Oregon. Transactions of the $63^{\text {rd }}$ North American Wildlife and Natural Resources Conference.

Ivey, G.L. and B.D. Dugger. 2008. Factors Influencing Nest Success of Greater Sandhill Cranes at Malheur National Wildlife Refuge, Oregon. Waterbirds. 31(1):52-61.

Ivey, G.L. 2009. Personal Correspondence with Malheur Refuge Biologist via telephone 325-09 and e-mail.

Johnson, D.H. 1979. Estimating nest success: The Mayfield method and an alternative. The Auk. 96(4):651-661.

Johnson, D. H. and T.L. Shaffer. 1990. Estimating Nest Success: When Mayfield Wins. Auk 107:595-600.

Klett, A.T., H.F. Duebbert, C.A. Faanes, and K.F. Higgins. 1986. Techniques for studying nest success of ducks in upland habitats in the Prairie Pothole Region. U.S. Fish and Wildlife Service, Resource Publication 158. Jamestown, ND: Northern Prairie Wildlife Research Center Online. http://www.npwrc.usgs.gov/resource/birds/nest/index.htm (Version 16JUL97).

Klett, A.T., T.L. Shaffer, and D.H. Johnson. 1988. Duck Nest Success in the Prairie Region. Journal of Wildlife Management. 52(3):431-440.

Langston, N. 2003. Where Land and Water Meet: A Western Landscape Transformed. Seattle, WA: University of Washington Press.

Leitao, A.B., J. Miller, J. Ahern, and K. McGarigal. 2006. Measuring Landscapes, A Planner's Handbook. Washington, D.C. Island Press.

MacArthur, R.H. and E.O. Wilson. 1967. The Theory of Island Biogeography. Reprinted 2001. Princeton, New Jersey: Princeton University Press.

Mayfield, H.F. 1961. Nesting success calculated from exposure. Wilson Bulletin. 73:255261. 
Mayfield, H.F. 1975. Suggestions for Calculating Nest Success. Wilson Bulletin. 87:456466.

McDonald, J.H. 2009. Handbook of Biological Statistics (2nd ed.). Sparky House Publishing, Baltimore, Maryland. pp. 160-164. Last accessed online 11/11/2010 http://udel.edu/ mcdonald/stattransform.html

McGarigal, K., S. A. Cushman, M. C. Neel, and E. Ene. 2002. FRAGSTATS: Spatial Pattern Analysis Program for Categorical Maps. Computer software program produced by the authors at the University of Massachusetts, Amherst. Available at the following web site: www.umass.edu/landeco/research/fragstats/fragstats.html

Naugle, D.E., K.F. Higgins, S.M. Nusser, and W.C. Johnson. 1999. Scale-dependent habitat use in three species of prairie wetland birds. Landscape Ecology. 14:267-276.

NAIP. 2005. National Agricultural Imagery Program. U.S. Department of Agriculture. Data available online. http://www.apfo.usda.gov/

NRCS. 2006. Soil Survey of Harney County Area, Oregon. Natural Resources Conservation Service. Data available online. http://soildatamart.nrcs.usda.gov/manuscripts/OR628/0/Harney.pdf

NWI. 1986. National Wetlands Inventory, Notes to Users, Malheur-Harney, Oregon. Data available online. http://www.fws.gov/wetlands/

Nilsson, L. 1978. Breeding Waterfowl in Eutrophicated Lakes in South Sweden. Wildfowl. 29:101-110.

Nudds, T.D. 1992. Patterns in Breeding Waterfowl Communities. In Ecology and Management of Breeding Waterfowl, eds. B.D.J. Batt, A.D. Afton, M.G. Anderson, C.D. Ankney, D.H. Johnson, J.A. Kadlec, and G.L. Krapu, pp. 540-567. Minneapolis, MN. University of Minnesota Press.

Olson, R. 1999. Constructing Wetlands in the Intermountain West: Guidelines for Land Resource Managers. Laramie, Wyoming. University of Wyoming.

Passinelli, G. and K. Schiegg. 2006. Fragmentation Within and Between Wetland Reserves: the Importance of Spatial Scales for Nest Predation in Reed Buntings. Ecography. 29:721-732.

Paton, P.W.C. 1994. The Effect of Edge on Avian Nest Success: How Strong is the Evidence? Conservation Biology. 8(1):17-26. 
Poole, A. 2009. eds. The Birds of North America Online. Cornell Lab of Ornithology, Ithaca. Retrieved May 19, 2009 from http://bna.birds.cornell.edu/bna/species/

R Development Core Team. 2008. R: A language and environment for statistical computing. R Foundation for Statistical Computing, Vienna, Austria. ISBN 3-900051-07-0, URL http://www.R-project.org.

Riffell, S.K., B.E. Keas, and T.M. Burton. 2001. Area and habitat relationships of birds in great lakes coastal wet meadows. Wetlands. 21(4):492-507.

Riffell, S.K., B.E. Keas, and T. M. Burton. 2003. Birds in Great Lakes coastal wet meadows: is landscape context important? Landscape Ecology. 18:95-111.

Rogerson, P.A. 2006. Statistical Methods for Geography. London: Sage Publications.

Rotella, J. 2008. Nest Survival Methods. Chapter 17 in, Cooch, E. and G. White. 2008. eds. Program MARK, A Gentle Introduction. $7^{\text {th }}$ Edition. Last accessed May 11, 2009 from http://www.phidot.org/software/mark/docs/book/

Skagen, S.K., A.A. Yackel Adams, and R.D. Adams. 2005. Nest Survival Relative to Patch Size in a Highly Fragmented Shortgrass Prairie Landscape. Wilson Bulletin. 117(1):23-34.

Stephens, S.E., D.N. Koons, J.J. Rotella, and D.W. Willey. 2003. Effects of habitat fragmentation on avian nesting success: a review of the evidence at multiple spatial scales. Biological Conservation. 115:101-110.

Taft, O.W. and S.M. Haig. 2006. Importance of wetland landscape structure to shorebirds wintering in an agricultural valley. Landscape Ecology. 21:169-184.

USFWS. 1976. Final Environmental Statement, Operation of the National Wildlife Refuge System. U.S. Department of the Interior, Fish and Wildlife Service. U.S. Government Printing Office: 1976 O-222-029.

USFWS. 1990. Blitzen Valley Management Plan. U.S. Fish and Wildlife Service. Malheur National Wildlife Refuge. Princeton, Oregon.

USFWS. 2003. Refuges 2003, Draft Environmental Impact Statement, a Plan for the Future of the National Wildlife Refuge System. U.S. Department of the Interior, Fish and Wildlife Service. 
USFWS. 2010. Comprehensive Conservation Plan, Draft. U.S. Fish and Wildlife Service. Malheur National Wildlife Refuge. Princeton, Oregon.

Weller, M.W. 1999. Wetland Birds: Habitat Resources and Conservation Implications. Cambridge, UK: Cambridge University Press.

Wiens, J.A. 1989. Spatial Scaling in Ecology. Functional Ecology. 3:385-397. 


\section{APPENDIX}

Correlation Matrix with Landscape-level Metrics

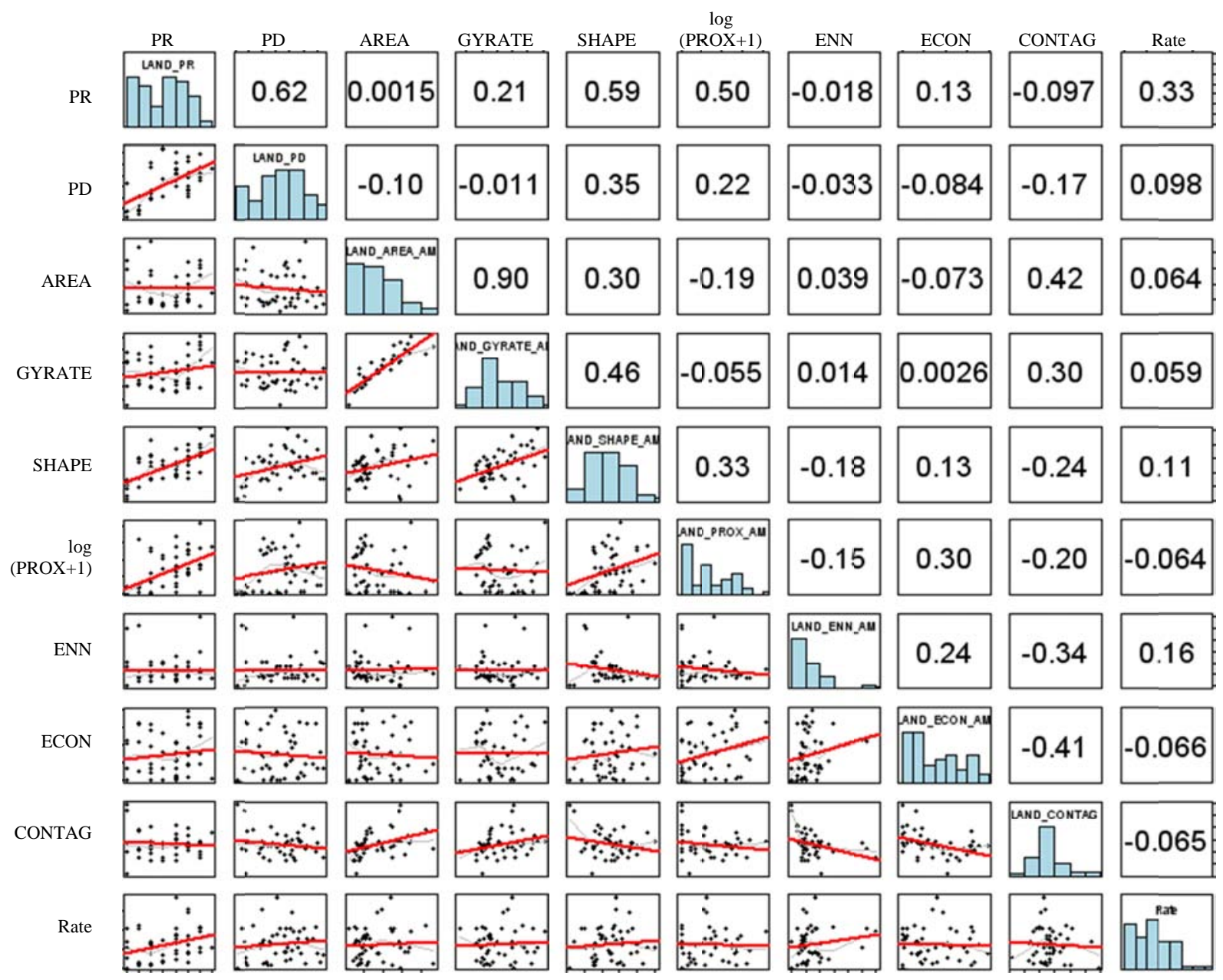

Correlation Matrix of landscape-level metrics and survival rate showing histograms as diagonal, $\mathrm{R}$ values above the diagonal, and scatterplots with an ordinary-least-squares regression line below the diagonal. 
Correlation Matrix with Class-level Metrics for Emergent Marsh

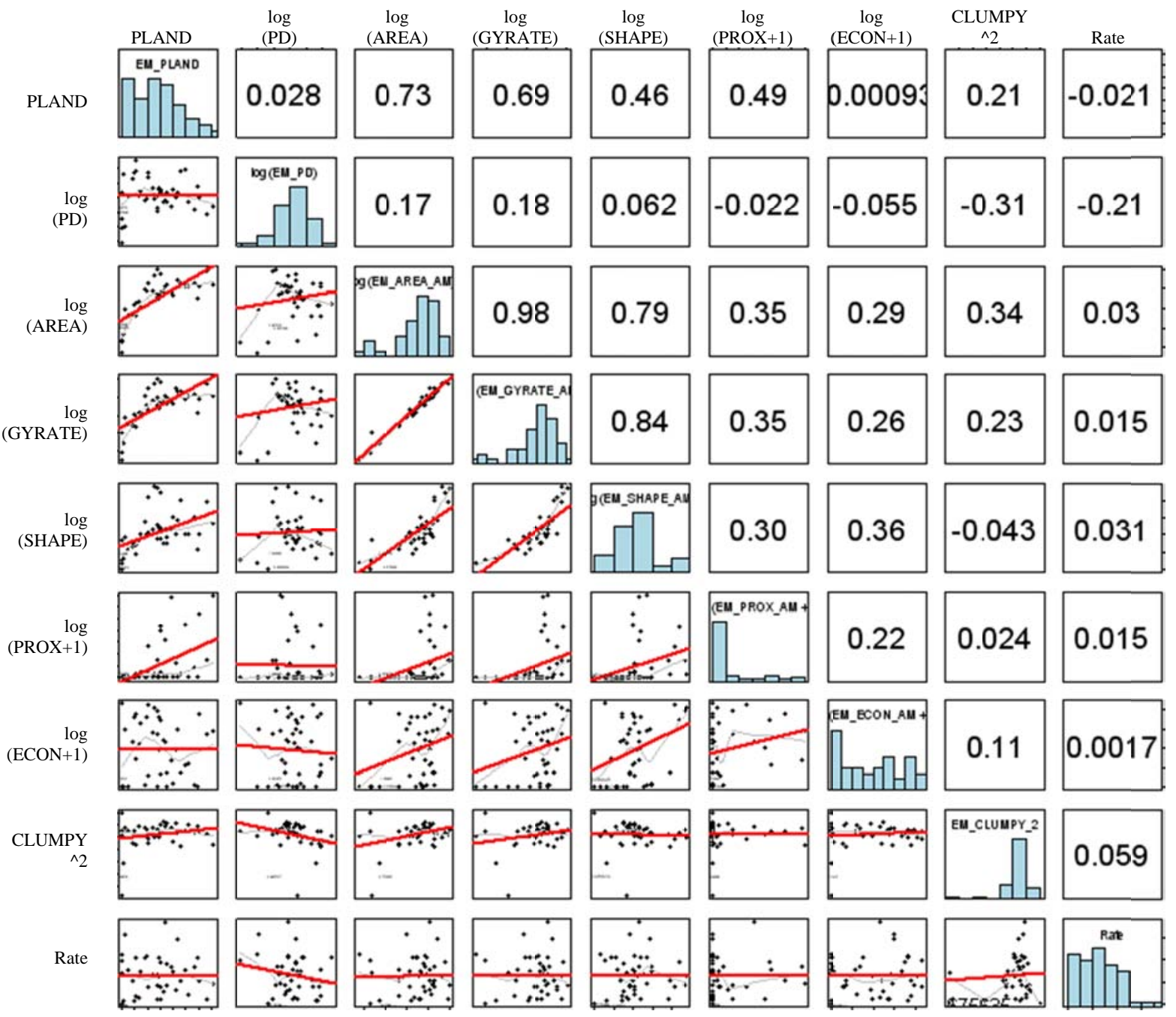

Correlation Matrix of class-level metrics for emergent marsh (except for ENN because of lower sample size) and survival rate showing histograms as diagonal, $\mathrm{R}$ values above the diagonal, and scatterplots with an ordinary-least-squares regression line below the diagonal. 
Correlation Matrix with Class-level Metrics for Wet Meadow

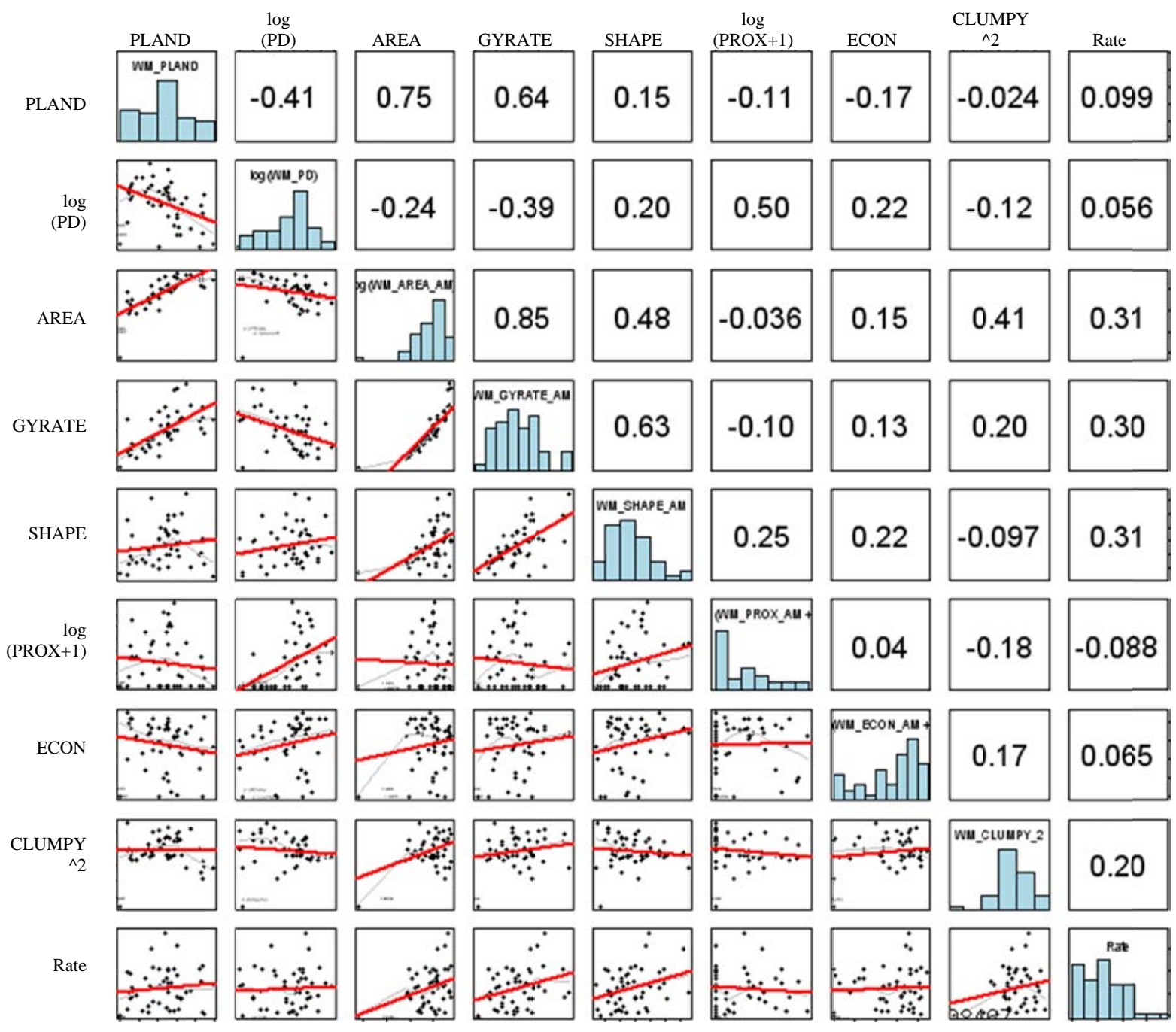

Correlation Matrix of class-level metrics for wet meadow (except for ENN because of lower sample size) and survival rate showing histograms as diagonal, $\mathrm{R}$ values above the diagonal, and scatterplots with an ordinary-least-squares regression line below the diagonal. 
Correlation Matrix with Class-level Metrics for Dry Meadow

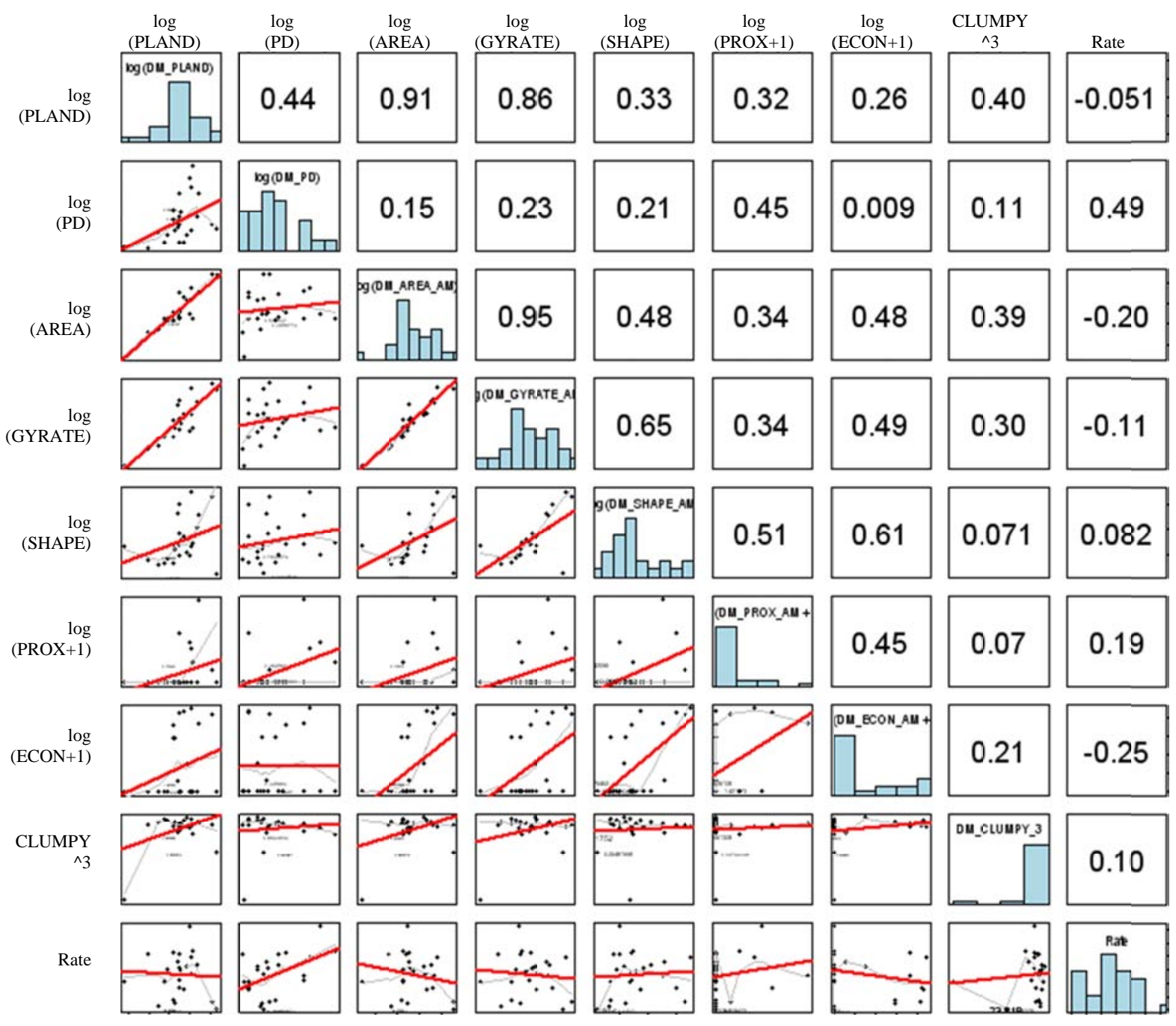

Correlation Matrix of class-level metrics for dry meadow (except for ENN because of lower sample size) and survival rate showing histograms as diagonal, $R$ values above the diagonal, and scatterplots with an ordinary-least-squares regression line below the diagonal. 